\title{
Variability in nitrogen and phosphorus limitation for Baltic Sea phytoplankton during nitrogen-fixing cyanobacterial blooms
}

\author{
P. H. Moisander ${ }^{1,2, *}$, T. F. Steppe ${ }^{1}$, N. S. Hall ${ }^{1}$, J. Kuparinen ${ }^{3}$, H. W. Paerl ${ }^{1}$ \\ ${ }^{1}$ Institute of Marine Sciences, University of North Carolina at Chapel Hill, 3431 Arendell Street, Morehead City, \\ North Carolina 28557, USA \\ ${ }^{2}$ Finnish Institute of Marine Research, Lypekinkuja 3A, PB 33, 00931 Helsinki, Finland \\ ${ }^{3}$ Department of Ecology and Systematics, Viikinkaari 1, PB 65, University of Helsinki, Helsinki, Finland
}

\begin{abstract}
Baltic Sea phytoplankton responses during $\mathrm{N}_{2}$-fixing cyanobacterial blooms, dominated by Nodularia spp., Aphanizomenon sp., and Anabaena spp., were studied using nutrient enrichment experiments. Nitrogen fixation, phytoplankton growth, primary productivity, and phytoplankton species' responses were investigated in areas representing open Baltic Sea water and Gulf of Finland water. Responses to additions of N, P, Fe, and the organic chelator EDTA were studied. Phytoplankton biomass and primary productivity were $\mathrm{N}, \mathrm{P}$, or $\mathrm{N}+\mathrm{P}$-limited. Phosphorus limitation was more prominent at the Gulf of Finland sites, where the dissolved inorganic-nitrogen to phosphorus (DIN:DIP) ratio was $>16: 1$ during the study period. At the open sea sites, with DIN:DIP ratio $<16: 1, N$ limitation or $\mathrm{N}+\mathrm{P}$ co-limitation prevailed. Phosphorus consistently stimulated $\mathrm{N}_{2}$ fixation, and at times $\mathrm{N}_{2}$ fixation and total $\mathrm{N}$ had a linear relationship with the initial $\mathrm{PO}_{4}{ }^{3-}$ concentration added. At other times, the relationship was not clear, suggesting other limitations or controls for $\mathrm{N}_{2}$ fixation. Occasionally, EDTA increased $\mathrm{N}_{2}$ fixation, but Fe addition did not show a significant impact on phytoplankton biomass, productivity, or $\mathrm{N}_{2}$ fixation. The chlorophyte Monoraphidium sp., diatom Nitzschia spp., and small flagellates $(7.5$ to $10 \mu \mathrm{m})$ were among the species that exhibited the fastest growth responses under replenishment of the limiting nutrient. The results suggest that high $\mathrm{N}$ availability, in relation to $\mathrm{P}$, in the coastal areas in the Gulf of Finland acts to reduce the relative abundance of $\mathrm{N}_{2}$ fixing organisms. Phosphorus inputs into the upper-mixed layer in the open sea during bloom periods stimulate $\mathrm{N}_{2}$ fixation, and act to maintain the cyanobacterial blooms.
\end{abstract}

KEY WORDS: Nodularia $\cdot$ Nitrogen fixation $\cdot$ Nutrient limitation $\cdot$ Cyanobacteria $\cdot$ Blooms $\cdot$ EDTA $\cdot$ Iron

Resale or republication not permitted without written consent of the publisher

\section{INTRODUCTION}

Variability in phytoplankton nutrient requirements and their acquisition mechanisms play a central role in defining phytoplankton community structure (Margalef 1978, Tilman 1982). Because of species-specific differences, changes in supply rates of nutrients and their concentrations will lead to modifications in the community structure. Knowledge of species-specific phytoplankton responses to nutrients is therefore useful when predicting phytoplankton community-composition under different nutrient dynamics. Phyto- plankton nutrient limitation is linked with nutrient limitations of the whole ecosystem, and information on nutrient limitations both of these scales is valuable when evaluating and predicting anthropogenic influences, including the effects of eutrophication.

Under persistent, low-nutrient concentrations, a phytoplankton community dominated by the species with the lowest resource (nutrient) requirement will develop (Tilman 1982). If nutrients are suddenly provided, opportunistic species efficient at nutrient uptake under high-nutrient conditions are expected to increase in abundance. If the dominant members in the 
prevailing community are able to compete for nutrients with the opportunists in this new situation, they may also benefit from such a nutrient pulse. Long-term development of the community is determined both by the ability of different species to compete for nutrients, and the frequency and magnitude of the nutrient inputs. Phytoplankton community shifts during cyanobacterial blooms in the nutrient-depleted surface layer in the Baltic Sea reflect such a situation. By late summer, $\mathrm{N}_{2}$-fixing cyanobacteria dominate the community under conditions of depleted inorganic $\mathrm{N}$ and $\mathrm{P}$ in the surface layer. $\mathrm{N}_{2}$-fixing cyanobacteria presumably have a competitive advantage by using $\mathrm{N}_{2}$ fixation as their $\mathrm{N}$-source, and by relying on stored $\mathrm{P}$ reserves for extended periods of time (Healey 1982). Possible modes of pulsed nutrient inputs to the upper mixed layer in the open Baltic Sea are: vertical transport from beneath the pycnocline induced by, e.g. wind events (Kononen et al. 1996); advection from coastal runoff; or atmospheric deposition, especially rain events (Paerl et al. 1999). The competitive interactions among different phytoplankton species in Baltic Sea cyanobacterial blooms during these nutrient-replenishment events are not clear.

The prevailing paradigm is that: (1) the open Baltic Sea is N-limited at the end of the summer; (2) this favors $\mathrm{N}_{2}$-fixing cyanobacterial blooms; and (3) based on concentrations of $\mathrm{P}$ before, during, and after the blooms, the $\mathrm{N}_{2}$-fixing cyanobacteria are P-limited. However, few studies have addressed nutrient/resource limitation of $\mathrm{N}_{2}$ fixation and growth of $\mathrm{N}_{2}$ fixers in the Baltic Sea in natural conditions (Wallström et al. 1992, Stal et al. 1999, Rydin et al. 2002). Nutrient-enrichment experiments have shown that, depending on season and study area, total phytoplankton growth and productivity in the Baltic Sea can be either N- or P-limited, or 'colimited' by $\mathrm{N}$ and $\mathrm{P}$ (Granéli et al. 1990, Kivi et al. 1993). During late summer, the overall $\mathrm{N}$ limitation of phytoplankton growth in the system is manifested as a dominance by $\mathrm{N}_{2}$-fixing planktonic cyanobacteria (Nodularia spp., Anabaena spp., and Aphanizomenon sp.). These species are not dependent on combined $\mathrm{N}$ in the environment, therefore the density of their blooms in the Baltic may be controlled by availability of the other major algal nutrient, P (Kahru et al. 2000); however, Fe limitation is also possible (Stahl et al. 1999). In lakes, if the molar ratio of inorganic $\mathrm{N}$ to $\mathrm{P}$ in nutrient loading is reduced to less than 16 (Redfield ratio), the likelihood for dominance by $\mathrm{N}_{2}$-fixing cyanobacteria increases (Flett et al. 1980, Levine \& Schindler 1999). The low ratio of total $\mathrm{N}$ to total P (TN:TP) in the water column is another indicator of increased potential for growth of $\mathrm{N}_{2}$ fixers (Smith 1983). By importing new N, $\mathrm{N}_{2}$ fixation may compensate for the overall $\mathrm{N}$ limitation in the system, and thus act to maintain the ratio of nutrients
(TN:TP) at close to optimal for phytoplankton growth $(16: 1)$. If this feedback mechanism works perfectly (with no time-lag and without losses of N), one would expect that in a system in which $\mathrm{N}_{2}$ fixers are dominating and limited by $\mathrm{P}$ only an increase in dissolved inorganic phosphorus (DIP) supply would be directly related to increases in $\mathrm{N}_{2}$ fixation and total $\mathrm{N}$. In this study we tested the accuracy of this hypothesis in Baltic Sea cyanobacterial blooms.

Variable N:P ratios in dissolved nutrients (DIN:DIP) in the Baltic Sea may lead to regional differences in $\mathrm{N}_{2}$-fixer abundances (Niemi 1979). The easternmost basin in the Baltic Sea, the Gulf of Finland, receives a major proportion of its nutrient load from the Neva River, a large river entering to the Gulf at its easternmost tip. This nutrient load has a DIN:DIP ratio of approximately 3 times the Redfield ratio, suggesting that the Gulf should be P-limited, and $\mathrm{N}_{2}$ fixation should not occur. However, limitation of primary productivity by both $\mathrm{N}$ and $\mathrm{P}$ may occur at the end of the summer (Kivi et al. 1993, Pitkänen \& Tamminen 1995). This may be due to estuarine nutrient retention processes and different nutrient ratios in the adjacent water masses (Baltic Sea deep water and surface water) that can affect the area (Pitkänen \& Tamminen 1995). In general, a counter-clockwise circulation pattern prevails in the Gulf, and can mix water from the Baltic Proper with water from riverine sources. However, because of the strong influence from the Neva River and the complex local-bottom topography, the Gulf of Finland needs to be considered a separate sea area from the Baltic Proper from a hydrodynamic perspective (Omstedt \& Axell 2003).

The overall goal of this study was to determine nutrient limitation for the late-summer phytoplankton in the Baltic Sea in areas experiencing varying nutrient-input sources. The areas studied over 3 summers included sites in the eastern Gulf of Finland and sites at its entrance. The goal was to distinguish nutrient effects on different components of the phytoplankton, especially on the $\mathrm{N}_{2}$-fixing cyanobacteria and their $\mathrm{N}_{2}$ fixation. The study addressed the question of whether $\mathrm{N}_{2}$ fixation during the Baltic Sea cyanobacterial blooms serves as a feedback mechanism during P-input events, and thereby whether it has control over the TN:TP ratio in the system. Along with the effects on $\mathrm{N}_{2}$ fixation, the study focused on the short-term effects of nutrient additions on the phytoplankton communitycomposition.

\section{MATERIALS AND METHODS}

Nutrient-addition experiments (bioassays) were carried out on board the RV 'Aranda' (Finnish Institute of 


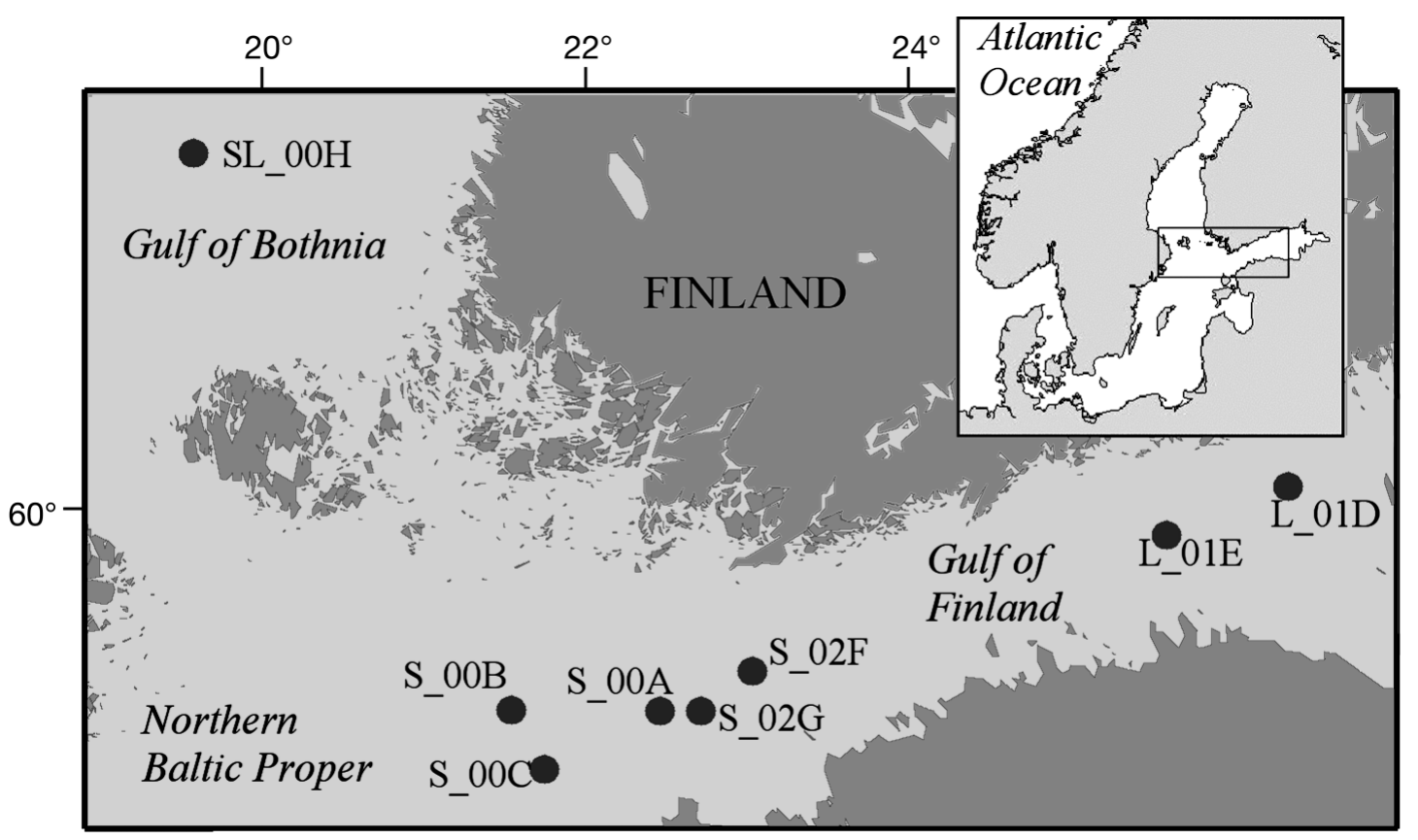

Fig. 1. Map of the study area. Codes for water sampling sites refer to experiments carried out with water from these sites: $\mathrm{S}$ and $\mathrm{L}$ denote open Baltic Sea and gulf waters, respectively; numbers refer to years sampled; letters A to H correspond to Sites A to H, e.g. S_00B corresponds to the open sea Site B sampled in 2000

Marine Research) in July/August 2000, 2001 and 2002 (Fig. 1, Table 1). Surface water was sampled using a 30 1 water sampler (in 2000), or by pumping surface water directly from ca. $1 \mathrm{~m}$ depth (in 2001 and 2002). The water sampling sites were designated as S_00A, S_00B, S_00C, L_01D, L_01E, S_02F, S_02G, and SL_00H (Fig. 1). Open sea water (S) and gulf water (L) are distinguished in these station codes, numbers refer to years sampled, and letters A to $\mathrm{H}$ correspond to Sites A to H. Designation of open sea water and gulf water was based on geographical location of the sampling sites, and salinities at the sites (Table 1). Incubations with nutrient additions were carried out in quadruplicate $1 \mathrm{l}$ acid-washed $(0.1 \mathrm{M} \mathrm{HCl})$ and deionized (DI)water-rinsed polyethylene Cubitainer (Hedwin Corp) (85\% transparent to photosynthetically active radiation), filled with $900 \mathrm{ml}$ sample water (Paerl et al. 1999). Mannitol $(10 \mu \mathrm{M}), \mathrm{NaNO}_{3}(10 \mu \mathrm{M})$, (concentrations in Cubitainers at the start of the experiment) $\mathrm{K}_{2} \mathrm{HPO}_{4}(2 \mu \mathrm{M}), \mathrm{FeCl}_{3}(0.4 \mu \mathrm{M})$ or EDTA $(0.4 \mu \mathrm{M})$, or combinations of these, were added to the Cubitainers. One set of Cubitainers did not receive nutrients and served as a control. These $\mathrm{NO}_{3}{ }^{-}$and $\mathrm{PO}_{4}{ }^{3-}$ additions represented a $>100$-fold increase in ambient nutrient

Table 1. Experimental design and conditions at the beginning of nutrient-addition bioassays. Temperature and salinity values are based on CTD measurements. Site codes: S and L denote open Baltic Sea and gulf waters, respectively; numbers refer to years sampled; letters A to H correspond to Sites A to H, e.g. S_00B corresponds to the open sea Site B sampled in 2000. DIN:DIP is dissolved inorganic nitrogen-to-phosphorus ratio; TN: total nitrogen; TP: total phosphorus; NA: not available

\begin{tabular}{|c|c|c|c|c|c|c|c|c|c|c|c|}
\hline Site & Date & $\begin{array}{c}\text { Location } \\
\text { (Lat., Long.) }\end{array}$ & $\begin{array}{l}\mathrm{PO}_{4}^{3-} \\
(\mu \mathrm{M})\end{array}$ & $\begin{array}{l}\mathrm{NH}_{4}^{+} \\
(\mu \mathrm{M})\end{array}$ & $\begin{array}{l}\mathrm{NO}_{\mathrm{x}}^{-} \\
(\mu \mathrm{M})\end{array}$ & $\begin{array}{l}\text { DI } \\
0 \mathrm{~m}\end{array}$ & $\begin{array}{l}\text { J:DIP } \\
0-10 \mathrm{~m}\end{array}$ & $\begin{array}{c}\mathrm{TP} \\
(\mu \mathrm{M})\end{array}$ & $\begin{array}{c}\mathrm{TN} \\
(\mu \mathrm{M})\end{array}$ & $\begin{array}{c}\text { Salinity } \\
\text { (psu) }\end{array}$ & $\begin{array}{l}\text { Temp. } \\
\left({ }^{\circ} \mathrm{C}\right)\end{array}$ \\
\hline S_00A & 18 July 2000 & $22^{\circ} 27.81^{\prime} \mathrm{E}, 59^{\circ} 22.00^{\prime} \mathrm{N}$ & 0.05 & 0.42 & 0.11 & 10.6 & 7.7 & NA & NA & 6.2 & 13.9 \\
\hline S_00B & 21 July 2000 & $21^{\circ} 32.55^{\prime} \mathrm{E}, 59^{\circ} 22.12^{\prime} \mathrm{N}$ & 0.07 & 0.31 & 0.03 & 4.9 & 12.9 & NA & NA & 6.3 & 14.8 \\
\hline S_00C & 24 July 2000 & $21^{\circ} 44.81^{\prime} \mathrm{E}, 59^{\circ} 11.00^{\prime} \mathrm{N}$ & 0.03 & 0.21 & 0.12 & 11 & 8.9 & NA & NA & 6.8 & 16.1 \\
\hline SL_0OH & 13 Aug 2000 & $19^{\circ} 34.79^{\prime} \mathrm{E}, 61^{\circ} 05.00^{\prime} \mathrm{N}$ & 0.02 & 0.07 & 0.09 & 8 & NA & 0.33 & 18.6 & 5.6 & 14.1 \\
\hline L_01D & 30 July 2001 & $26^{\circ} 20.82^{\prime} \mathrm{E}, 60^{\circ} 04.04^{\prime} \mathrm{N}$ & 0.00 & 0.28 & 0.09 & NA & 35 & 0.28 & 28.5 & 4.5 & 21.5 \\
\hline L_01E & 3 Aug 2001 & $25^{\circ} 35.83^{\prime} \mathrm{E}, 59^{\circ} 55.01^{\prime} \mathrm{N}$ & 0.00 & 0.15 & 0.06 & NA & 20 & 0.45 & 25.1 & 4.8 & 17.5 \\
\hline S_02F & 15 July 2002 & $23^{\circ} 02.15^{\prime} \mathrm{E}, 59^{\circ} 29.46^{\prime} \mathrm{N}$ & 0.05 & NA & 0 & NA & NA & NA & NA & 5.6 & 18.4 \\
\hline S_02G & 19 July 2002 & $22^{\circ} 43.08^{\prime} \mathrm{E}, 59^{\circ} 22.03^{\prime} \mathrm{N}$ & 0.06 & NA & 0.01 & 0.05 & 0.06 & NA & NA & 5.8 & 19.5 \\
\hline
\end{tabular}


levels. Cubitainers were incubated for 3 to $4 \mathrm{~d}$ under natural irradiance on the deck of the ship in tubs with constantly circulating surface water, and sampled at $24 \mathrm{~h}$ intervals for detection of $\mathrm{N}_{2}$ fixation rates, chl $a_{\text {, }}$ and primary productivity. At the end of the experiments, samples were preserved with Lugol's solution for microscopic analyses. The tubs were covered with screens during strong sunlight to alleviate photoinhibition. An additional set of experiments specifically addressed the effect of $\mathrm{P}$ on $\mathrm{N}_{2}$ fixation and TN. In these experiments, a range of $\mathrm{PO}_{4}{ }^{3-}$ concentrations were added to sample water in 41 Cubitainers, and $3 \mathrm{~d}$ long incubations were carried out as described above. In one of these 'P-experiments' (Site SL_00H), in order to increase the abundance of filamentous cyanobacteria, a concentrated sample, collected using a $100 \mu \mathrm{m}$ mesh-size net and diluted with surface water, was used.

Primary productivity was measured using the ${ }^{14} \mathrm{C}$ technique as described by Parsons et al. (1984), either directly in the Cubitainers (in 2000) or by carrying out a separate incubation $(4 \mathrm{~h})$ on subsamples from Cubitainers (in 2001). At the end of the incubation, subsamples were filtered, filters fumed using concentrated $\mathrm{HCl}$ to remove unincorporated ${ }^{14} \mathrm{C}$, and radioactivity was measured in a scintillation counter (Wallac 1400). In 2000, at the termination of incubation, the primary productivity samples were filtered on GF/F glass fiber filters (Whatman). In 2001, the productivity samples were separated into microplanktonic $(>2 \mu \mathrm{m})$ and picoplanktonic ( 0.2 to $2 \mu \mathrm{m}$ ) size fractions at the end of the incubation. For the fractionation, the samples were first filtered through $2 \mu \mathrm{m}$ polycarbonate filters (Poretics), the filtrate was then further filtered on $0.2 \mu \mathrm{m}$ pore-size polycarbonate filters (Poretics), and radioactivity was measured on each of these filters. Dark fixation was subtracted from light fixation in 2001. Mean dark fixation was $11.6 \%$ of light fixation (SD 9.6). Assimilation numbers were calculated in 2001 by dividing the productivity ( $\mu \mathrm{C} \mathrm{Cl}^{-1} \mathrm{~h}^{-1}$ ) values by chl $a$ concentration. For chl a measurements, samples were filtered on GF/F filters, filters were blotted dry, and then frozen $\left(-20^{\circ} \mathrm{C}\right)$. Samples were extracted overnight with ethanol in the dark at room temperature, filtered through GF/Fs to remove particles, and measured at 668 to $672 \mathrm{~nm}$ using a spectrofluorometer (PerkinElmer LS-2B or Jasco FP-750). Nitrogen fixation was detected using the acetylene reduction (AR) assay (Burris 1972). Nine ml of acetylene generated from calcium carbide was added to $90 \mathrm{ml}$ of sample water in $117 \mathrm{ml}$ serum vials. At the end of a 4 to $5 \mathrm{~h}$ incubation in the circulating seawater tub, vials were vigorously shaken for $20 \mathrm{~s}$ to equilibrate gases between liquid and gas phases, and gas was transferred from the headspace to evacuated blood-collection tubes (Vacu- tainers, Becton Dickinson). Vacutainers were opened and aired out overnight, and manually re-evacuated before use. Ethylene concentration was measured on the Vacutainer contents using a Shimadzu GC-9A gas chromatograph, equipped with a flame ionization detector and a Porapak $\mathrm{T}$ stainless steel column at $80^{\circ} \mathrm{C}$, using $\mathrm{N}_{2}$ as a carrier gas. The gas chromatograph was calibrated daily using ethylene standards. $\mathrm{N}_{2}$ fixation values were reported as acetylene reduced per volume ( $\mathrm{NF}_{\text {; }}$ nmol $\mathrm{C}_{2} \mathrm{H}_{4} \mathrm{l}^{-1} \mathrm{~h}^{-1}$ ) and normalized to chl a ( $\left.\mathrm{NR}_{i} \mathrm{nmol} \mathrm{C}_{2} \mathrm{H}_{4} \mu \mathrm{g} \mathrm{chl} a^{-1} \mathrm{~h}^{-1}\right)$. Dissolved and total nutrients were measured onboard following the guidelines for the Baltic Marine Environment Protection Commission (1983).

Numbers of dominant phytoplankton species or groups were determined by microscopy from samples preserved in Lugol's solution. Cells were counted by the settling technique using a Thomas Scientific inverted phase-contrast microscope. $\mathrm{N}_{2}$-fixing cyanobacteria were counted in units of $100 \mu \mathrm{m}$ filaments. At least 50 cells or counting units per species reported were counted per sample. Small flagellates included cells from 7.5 to $10 \mu \mathrm{m}$ diameter. In 2002, a large proportion of the Nodularia spp. filaments contained empty cells. The filaments that were composed of $1 / 2$ empty cells or greater were reported as 'old', and the rest of the filaments were reported as 'young'. Filament units were converted to $C$ using 1170,175 , and $215 \mathrm{pg} \mathrm{C}$ for each $100 \mu \mathrm{m}$ filament fragment of Nodularia sp., Aphanizomenon sp., and Anabaena spp., respectively.

Repeated measures ANOVA (e.g. Underwood 1997) or 1-way ANOVA were used in statistical comparisons between treatments. Repeated measures ANOVA was used for data sets with multiple-sampling time points, and 1-way ANOVA was used for single time-point data sets. Normality of data and homogeneity of variances were studied before ANOVA tests using the Kolmogorov-Smirnov test with a Lilliefors significance level (SPSS ${ }^{\odot}$ 9.0), and Cochran's test, respectively. Data were transformed, if necessary, to improve fit, and in most cases this satisfied the test assumptions. ANOVA was carried out also in the cases where small deviations from normality or non-homogenous variances were detected, even after transformations. In relatively large data sets and balanced experiments such as ours, small deviations from ANOVA testassumptions are not likely to affect conclusions (Underwood 1997). For pair-wise comparisons, Bonferroni (used if variances were homogenous) or Dunnet's T3 (used if variances were non-homogenous) post hoc tests were used for $\mathrm{N}_{2}$ fixation, $\mathrm{chl} a_{1}$ and productivity data. For phytoplankton abundance data, Dunnet's post hoc test (comparison of treatment effects to predetermined control) was used. Statistical tests were not 
carried out if there were too few cells for detection in some treatments. Unless specified, a probability level of $\alpha \leq 0.05$ was used to indicate statistically significant differences. Linear regressions, with significances tested, were fitted (Sigma Plot 2000 v. 6.00) for responses in experiments addressing the relationship between $\mathrm{PO}_{4}{ }^{3-}$ concentration and $\mathrm{N}_{2}$ fixation, chl $a_{\text {, }}$ and total N (Sites L_01D, L_01E, SL_00H).

\section{RESULTS}

\section{Ambient conditions}

The ratio of dissolved inorganic nutrients (DIN:DIP) was lower than the Redfield ratio at sites sampled in 2000 (open sea: Sites S_00A, S_00B, S_00C, SL_00H), and higher than the Redfield ratio at sites sampled in 2001 (gulf: Sites L_01D, L_01E) (Fig. 2, Table 1). Molar TN:TP ratios, measured in 2000 and 2001, were between 55.8 and 101.8. Surface water used in experiments in 2000 had lower temperatures, higher salinities, and higher $\mathrm{PO}_{4}{ }^{3-}-\mathrm{P}$ concentrations than in 2001 (Table 1). In 2002, $\mathrm{PO}_{4}{ }^{3-}-\mathrm{P}$ concentrations were similar to those in 2000, while $\mathrm{NO}_{\mathrm{x}}{ }^{-}-\mathrm{N}$ was lower. Water temperatures were lower in 2000 than in 2001 and 2002. Nodularia spp. dominated the $\mathrm{N}_{2}$-fixing cyanobacteria and the whole phytoplankton community at most sites in all study years (Tables $2 \& 3$ ). The only site where Aphanizomenon sp. dominated was at S_00A. In 2001 and 2002, cell numbers of Aphanizomenon sp. and Anabaena spp. were at the same, relatively low levels (Sites L_01D, L_01E, S_02F and S_02G).

\section{Bioassay responses}

All sites sampled in 2000 represented open Baltic Sea water (S), and the greatest effect on total phytoplankton biomass ( $\mathrm{chl}$ a) was produced by the combined addition of $\mathrm{N}$ and P (Fig. 3, Table 4). N alone also stimulated biomass at all sites in 2000. A similar level of biomass enhancement was seen in the $\mathrm{N}+\mathrm{Fe}$ treatment, suggesting no additional effect from Fe (Fig. 3, Table 4). P alone and Fe+EDTA also stimulated biomass at some sites. Treatment effects on primary productivity were closely similar to effects on chl a (Table 4).

In 2001, both sites sampled represented gulf water (L). Phosphorus limitation dominated at these sites, although more at Site L_01D than L_01E. At Site L_01D, only treatments including P stimulated the phytoplankton biomass (chl a) (Fig. 3, Table 4). Significant differences from the control were also seen with $\mathrm{N}+\mathrm{P}, \mathrm{P}+\mathrm{Fe}$, and $\mathrm{N}+\mathrm{P}+\mathrm{Fe}$ treatments, but these were not significantly different from treatments where $\mathrm{P}$ was added alone. Primary productivity at Site L_01D in both 0.2 to $2 \mu \mathrm{m}$ and $>2 \mu \mathrm{m}$ size-fractions was significantly higher in treatments with $\mathrm{P}$ than other treatments (Fig. 4). At Site L_01E, neither N nor P stimulated chl a significantly when added alone, but when added in combination $(\mathrm{N}+\mathrm{P}$ and $\mathrm{N}+\mathrm{P}+\mathrm{Fe})$, these nutrients significantly increased chl a to higher levels than the control. However, both $\mathrm{P}$ addition alone and $\mathrm{N}+\mathrm{P}$ additions induced a significant increase in primary productivity at Site L_01E. In the picoplanktonic $(0.2$ to $2 \mu \mathrm{m})$ size fraction at Site L_01E, only P stimulated primary productivity (no significant difference between $\mathrm{P}, \mathrm{N}+\mathrm{P}$, and $\mathrm{N}+\mathrm{P}+\mathrm{Fe}$ ). Both $\mathrm{P}$ and $\mathrm{N}$ had a stimulatory effect on primary productivity in the size fraction $>2 \mu \mathrm{m}$ (significantly higher productivity under $\mathrm{N}+\mathrm{P}$ addition than under P-addition only). Iron addition had no effect on chl a or primary productivity at any sites. Results of statistical comparisons of assimilation number $\left(\mu \mathrm{g} \mathrm{C} \operatorname{chl~} a^{-1} \mathrm{~h}^{-1}\right)$ in different treatments were identical with comparisons of primary productivity ( $\mu \mathrm{C} \mathrm{Cl}^{-1} \mathrm{~h}^{-1}$ ) (Table 4 ).

P stimulated NF at all open sea sites, both in 2000 and 2002 (Fig. 5). Fe+EDTA and N+P addition also stimulated NF at several open sea sites (Fig. 5). P+Fe addition stimulated NF at Site S_00C, but not more than P-alone, or N+P. At Site S_00A, the mannitol and Fe (added without EDTA) also appeared to enhance NF, although only slightly. Results of NR were slightly different from NF (Table 4). The effect of P on NR was not quite as consistent as on NF. At Site S_00A, a negative impact on NR was seen in treatments where $\mathrm{N}$ was added. Low $\mathrm{N}_{2}$-fixation rates were detected at Site L_01D (Fig. 5), and no significant differences in $\mathrm{N}_{2}$ fixation (NF and NR) between nutrient treatments were seen at this site. At Site L_01E, $\mathrm{P}, \mathrm{N}+\mathrm{P}, \mathrm{P}+\mathrm{Fe}$, and $\mathrm{N}+\mathrm{P}+\mathrm{Fe}$ stimulated $\mathrm{NF}$, while $\mathrm{NR}$ was stimulated only by $\mathrm{P}$ (Fig. 5, Table 4).

In the open sea sites sampled in 2000, Monoraphidium sp., Nitzschia spp., and small flagellates were

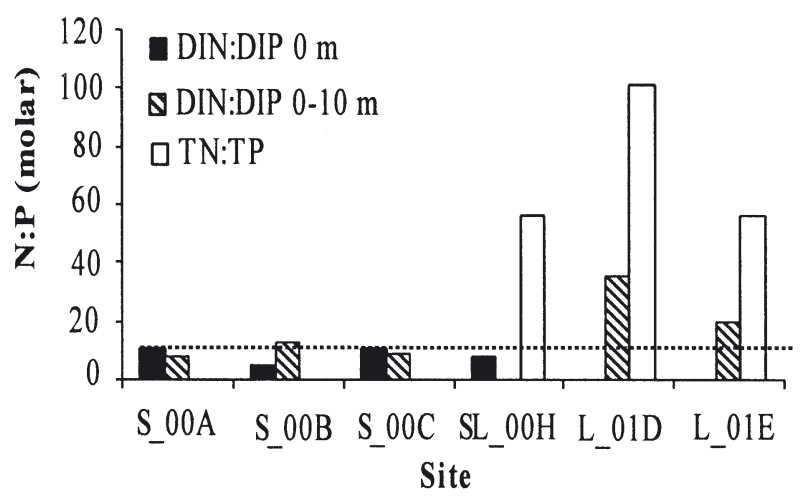

Fig. 2. Dissolved inorganic nitrogen-to-phosphorus (DIN:DIP) and total N to total P (TN:TP; molar) ratios at Sites A to E. Dotted line indicates the Redfield ratio. See Fig. 1 legend for site definitions 
Table 2. Phytoplankton abundances (mean \pm SD) from 2 independent containers per treatment. Dominating species in different treatments are shown. Numbers of the filamentous cyanobacteria Nodularia spp., Aphanizomenon sp. and Anabaena spp. are shown as $100 \mu \mathrm{m}$ units $\mathrm{ml}^{-1}$, the colonial chlorophyte is shown as colonies $\mathrm{ml}^{-1}$, and other species are shown as cells $\mathrm{ml}^{-1}$. Bold numbers indicate a significant difference from control (1-way ANOVA, Dunnet's post hoc comparison with control). Percentage of total cyanobacterial biomass was calculated based on conversion of filament units to C. bd: values below detection. Site codes: $\mathrm{S}$ and L denote open Baltic Sea and gulf waters, respectively; numbers refer to years sampled; letters A to E correspond to Sites A to E, e.g. S_00B corresponds to the open sea Site B sampled in 2000

\begin{tabular}{|c|c|c|c|c|c|c|}
\hline Site & Species/genus & $\%$ C in cyanobacteria & Control & $\mathrm{N}$ & $\mathrm{P}$ & $\mathrm{N}+\mathrm{P}$ \\
\hline S_00A & $\begin{array}{l}\text { Nodularia spp. } \\
\text { Anabaena spp. } \\
\text { Aphanizomenon sp. } \\
\text { Planktonema lauterb } \\
\text { Monoraphidium sp. } \\
\text { Small flagellates }\end{array}$ & ornii & $\begin{aligned} 466 & \pm 72 \\
654 & \pm 43 \\
7643 & \pm 4444 \\
42 & \pm 23 \\
5 & \pm 3 \\
2059 & \pm 44\end{aligned}$ & $\begin{aligned} 474 & \pm 44 \\
496 & \pm 309 \\
6100 & \pm 1623 \\
49 & \pm 16 \\
12 & \pm 1 \\
3640 & \pm 539\end{aligned}$ & $\begin{aligned} 769 & \pm 261 \\
645 & \pm 130 \\
7373 & \pm 2591 \\
45 & \pm 1 \\
6 & \pm 1 \\
2733 & \pm 618\end{aligned}$ & $\begin{aligned} 858 & \pm 520 \\
637 & \pm 151 \\
4775 & \pm 792 \\
49 & \pm 7 \\
\mathbf{2 3} & \pm \mathbf{6} \\
\mathbf{8 1 5 0} & \pm \mathbf{2 4 3 4}\end{aligned}$ \\
\hline S_00B & $\begin{array}{l}\text { Nodularia spp. } \\
\text { Anabaena spp. } \\
\text { Aphanizomenon sp. } \\
\text { P. lauterbornii } \\
\text { Monoraphidium sp. } \\
\text { Small flagellates }\end{array}$ & $\begin{array}{c}80 \\
3.4 \\
16.6\end{array}$ & $\begin{aligned} 2857 & \pm 316 \\
820 & \pm 261 \\
3222 & \pm 1313 \\
32 & \pm 2 \\
2 & \pm 0 \\
1365 & \pm 66\end{aligned}$ & $\begin{aligned} 3156 & \pm 149 \\
799 & \pm 211 \\
2643 & \pm 172 \\
57 & \pm 11 \\
\mathbf{1 2} & \pm \mathbf{2} \\
2935 & \pm 801\end{aligned}$ & $\begin{aligned} 3012 & \pm 901 \\
\mathbf{1 1 7 0} & \pm \mathbf{2 5 2} \\
2701 & \pm 1195 \\
50 & \pm 2 \\
5 & \pm 1 \\
2148 & \pm 54\end{aligned}$ & $\begin{aligned} 3046 & \pm 277 \\
768 & \pm 267 \\
1672 & \pm 743 \\
48 & \pm 11 \\
\mathbf{1 4} & \pm \mathbf{3} \\
\mathbf{9 7 2 1} & \pm \mathbf{2 1 6 7}\end{aligned}$ \\
\hline S_00C & $\begin{array}{l}\text { Nodularia spp. } \\
\text { Anabaena spp. } \\
\text { Aphanizomenon sp. } \\
\text { P. lauterbornii } \\
\text { Monoraphidium sp. } \\
\text { Small flagellates } \\
\text { Nitzschia spp. (epiph }\end{array}$ & $\begin{array}{lc} & 87.4 \\
& 2.1 \\
10.5 \\
\\
\\
\\
\\
\\
\\
\\
\\
\\
\\
\end{array}$ & $\begin{aligned} & 1453 \pm 91 \\
& 230 \pm 21 \\
& 950 \pm 149 \\
& 30 \pm 3 \\
& 4 \pm 1 \\
& 2666 \pm 540 \\
& \text { bd }\end{aligned}$ & $\begin{aligned} 1692 & \pm 512 \\
193 & \pm 153 \\
1310 & \pm 275 \\
29 & \pm 9 \\
7 & \pm 3 \\
2961 & \pm 478 \\
\text { bd } & \end{aligned}$ & $\begin{aligned} 1772 & \pm 151 \\
336 & \pm 223 \\
1033 & \pm 38 \\
29 & \pm 7 \\
5 & \pm 0 \\
3246 & \pm 404 \\
2 & \pm 1\end{aligned}$ & $\begin{aligned} 1694 & \pm 45 \\
363 & \pm 177 \\
1478 & \pm 2256 \\
18 & \pm 4 \\
\mathbf{2 1} & \pm \mathbf{3} \\
6403 & \pm 4731 \\
12 & \pm 6\end{aligned}$ \\
\hline L_01D & $\begin{array}{l}\text { Nodularia spp. } \\
\text { Anabaena spp. } \\
\text { Aphanizomenon sp. } \\
\text { P. lauterbornii } \\
\text { Monoraphidium sp. } \\
\text { Small flagellates } \\
\text { Nitzschia spp. } \\
\text { Chlorophyta colony } \\
\text { Chlorophyta } 2\end{array}$ & $\begin{array}{c}99.8 \\
0.1 \\
0.1\end{array}$ & $\begin{aligned} & 6431 \pm 233 \\
& 56 \pm 1 \\
& 23 \pm 76 \\
& 4 \pm 1 \\
& 8 \pm 2 \\
& 3154 \pm 2006 \\
& \text { bd } 2 \pm 1 \\
& \text { bd }\end{aligned}$ & $\begin{aligned} & \mathbf{8 5 8 5} \pm \mathbf{9 1 0} \\
& 94 \pm 3 \\
& 586 \pm 2023 \\
& 3 \pm 2 \\
& 6 \pm 2 \\
& 2081 \pm 91 \\
& \text { bd } \\
& 3 \pm 0 \\
& \text { bd }\end{aligned}$ & $\begin{aligned} 6963 & \pm 455 \\
169 & \pm 123 \\
238 & \pm 446 \\
8 & \pm 1 \\
10 & \pm 3 \\
4790 & \pm 721 \\
5 & \pm 1 \\
4 & \pm 2 \\
8 & \pm 7\end{aligned}$ & $\begin{aligned} 6664 & \pm 20 \\
47 & \pm 76 \\
5 & \pm 14 \\
7 & \pm 3 \\
36 & \pm 27 \\
6229 & \pm 1407 \\
4 & \pm 1 \\
6 & \pm 1 \\
11 & \pm 4\end{aligned}$ \\
\hline L_01E & $\begin{array}{l}\text { Nodularia spp. } \\
\text { Anabaena spp. } \\
\text { Aphanizomenon sp. } \\
\text { P. lauterbornii } \\
\text { Monoraphidium sp. } \\
\text { Small flagellates } \\
\text { Nitzschia spp. } \\
\text { D. acuminata } \\
\text { Dinoflagellate } 1 \\
\text { Dinoflagellate } 2 \\
\text { Chlorophyta colony }\end{array}$ & $\begin{array}{c}99.6 \\
0.3 \\
0.1\end{array}$ & $\begin{aligned} & 4504 \pm 1280 \\
& 105 \pm 152 \\
& 21 \pm 39 \\
& 28 \pm 15 \\
& 6 \pm 0 \\
& 1546 \pm 194 \\
& \text { bd } \\
& 1 \pm 0 \\
& 6 \pm 4 \\
& 1 \pm 0 \\
& 4 \pm 2\end{aligned}$ & $\begin{aligned} 5872 & \pm 1009 \\
191 & \pm 74 \\
58 & \pm 102 \\
32 & \pm 4 \\
7 & \pm 3 \\
1526 & \pm 486 \\
5 & \pm 1 \\
1 & \pm 0 \\
15 & \pm 7 \\
3 & \pm 1 \\
4 & \pm 0\end{aligned}$ & $\begin{aligned} 3415 & \pm 3380 \\
157 & \pm 13 \\
135 & \pm 446 \\
44 & \pm 1 \\
23 & \pm 5 \\
1463 & \pm 33 \\
1 & \pm 0 \\
1 & \pm 0 \\
5 & \pm 7 \\
0 & \pm 1 \\
5 & \pm 1\end{aligned}$ & $\begin{aligned} 5527 & \pm 599 \\
150 & \pm 73 \\
240 & \pm 4 \\
59 & \pm 13 \\
\mathbf{5 2} & \pm \mathbf{1 0} \\
2858 & \pm 1875 \\
113 & \pm 57 \\
\mathbf{2} & \pm \mathbf{0} \\
12 & \pm 8 \\
5 & \pm 2 \\
\mathbf{1 1} & \pm \mathbf{3}\end{aligned}$ \\
\hline
\end{tabular}

among the organisms responsible for the increased chl $a$ in response to $\mathrm{N}$ and $\mathrm{N}+\mathrm{P}$ (Table 2). Anabaena sp. biomass increased under P-treatment at Site S_00B ( $\mathrm{p}=0.058, \mathrm{n}=8$; Dunnet's post hoc test), while at all other sites, the biomasses of $\mathrm{N}_{2}$-fixing cyanobacteria in $\mathrm{N}, \mathrm{P}$, and $\mathrm{N}+\mathrm{P}$ treatments were not significantly different from control. At Site S_00C, a stimulation in numbers of a Nitzschia sp. attached to Nodularia spp. filaments was observed in response to N+P (Table 2).

Similar responses of phytoplankton communities in response to limiting nutrients were observed at gulf sites. P appeared to increase Anabaena spp. growth at Site L_01D, and P and N+P increased Aphani- zomenon sp. growth at Site L_01E (statistically nonsignificant difference from control). Addition of $\mathrm{P}$, or combined addition of $\mathrm{N}$ and $\mathrm{P}$, stimulated growth of Aphanizomenon, Monoraphidium sp., Planktonema lauterbornii (an unidentified colonial green alga), Nitzschia spp., Chlorophyceae Type 2 (Oocystis spp. type, colonial), Dinophysis acuminata, and small flagellates. The responses differed slightly in experiments at Sites L_01D and L_01E, and they were not always statistically significant (Table 2). For example, only P stimulated Nitzschia spp. at Site L_01D, while at Site L_01E, N-addition further increased their biomass. 
Table 3. Numbers of dominating species under different treatments at Sites S_02F and S_02G. Numbers of the filamentous cyanobacteria Nodularia spp., Aphanizomenon sp. and Anabaena spp. are shown as $100 \mu \mathrm{m}$ units $\mathrm{ml}^{-1}$. - $\mathrm{Y}$ and $-\mathrm{O}$ denote young and old (more than half of the cells in the filament were empty) filaments, respectively. Percentage of total cyanobacterial biomass was calculated based on conversion of filament units to C. Site codes: S denotes open Baltic Sea; numbers refer to years sampled; letters F and G correspond to Sites F and G, e.g. S_02F corresponds to the open sea Site F sampled in 2002

\begin{tabular}{|llccccc|}
\hline Site & \multicolumn{1}{c}{ Genus } & \% C in cyanobacteria & Control & P & P+EDTA & P+Fe+EDTA \\
\hline S_02F & Nodularia spp.-Y & 49.1 & $1996 \pm 162$ & $2376 \pm 725$ & $2878 \pm 1216$ & $4039 \pm 65$ \\
& Nodularia spp.-O & 50 & $2031 \pm 820$ & $2349 \pm 1205$ & $3824 \pm 189$ & $3312 \pm 482$ \\
& Anabaena spp. & 0.6 & $155 \pm 93$ & $157 \pm 5$ & $364 \pm 334$ & $477 \pm 209$ \\
& Aphanizomenon sp. & 0.3 & $71 \pm 211$ & $68 \pm 191$ & $619 \pm 1624$ & $470 \pm 174$ \\
S_02G & Nodularia spp.-Y & 36.6 & $1603 \pm 489$ & $1580 \pm 285$ & $1123 \pm 349$ & $1621 \pm 153$ \\
& Nodularia spp.-O & 60.2 & $2637 \pm 356$ & $1718 \pm 921$ & $3270 \pm 829$ & $3880 \pm 453$ \\
& Anabaena spp. & 0.5 & $147 \pm 36$ & $264 \pm 351$ & $381 \pm 218$ & $403 \pm 320$ \\
& Aphanizomenon sp. & 2.7 & $640 \pm 759$ & $798 \pm 47$ & $1364 \pm 700$ & $1021 \pm 1237$ \\
& & & & & & \\
\hline
\end{tabular}

To further study the impacts of $\mathrm{P}$ limitation on $\mathrm{N}_{2}$ fixation and the possibility that Fe limits $\mathrm{N}_{2}$ fixation, the test design in 2002 specifically targeted $\mathrm{P}$ and $\mathrm{Fe}$, while $\mathrm{N}$ addition was not included. Both sites sampled in 2002 represented open Baltic Sea water. At Site S_02F, the only treatment that did not increase phytoplankton growth was Fe (Fig. 3, Table 4). P alone, EDTA alone, $\mathrm{P}+\mathrm{EDTA}, \mathrm{Fe}+\mathrm{EDTA}, \mathrm{P}+\mathrm{Fe}$, and $\mathrm{P}+\mathrm{Fe}+\mathrm{EDTA}$ treatments all increased chl a over the control. $\mathrm{N}_{2}$ fixation (both $\mathrm{NF}$ and NR) responded in the same way as chl $a_{\text {, except }}$ EDTA had an additional stimulatory effect on NF (NF was higher under $\mathrm{P}+\mathrm{EDTA}$ and $\mathrm{P}+\mathrm{Fe}+\mathrm{EDTA}$ than if $\mathrm{P}$ was added alone) (Fig. 5). For Site S_02G, P added alone and P+EDTA increased chl a over the control. For $\mathrm{N}_{2}$ fixation (NF and NR), a significant increase over the control was found for all treatments that included P. $\mathrm{NF}$ and NR in these treatments were at the same level (non-significant differences between treatments). Some increases in abundances of Nodularia spp., Anabaena spp. and Aphanizomenon sp. in response to nutrient additions were present in P+EDTA, $\mathrm{P}+\mathrm{Fe}+\mathrm{EDTA}$ and $\mathrm{P}$-alone treatments, but these differences were not significant (Table 3).

\section{Effects of variable $P$ additions}

A set of experiments used a range of $\mathrm{PO}_{4}{ }^{3-}$ concentrations to address the degree of $\mathrm{P}$ limitation. At Site SL_00H, chl a, NF, and TN had a strong, positive, significant linear relationship with amount of $\mathrm{PO}_{4}{ }^{3-}$ added (Fig. 6). At Site L_01D, chl a showed the same relationship with $\mathrm{PO}_{4}{ }^{3-}$ additions (Fig. 6). $\mathrm{N}_{2}$ fixation was low at Site L_01D, but had a positive relationship with $\mathrm{PO}_{4}{ }^{3-}$ additions. Total $\mathrm{N}$ concentration after the $72 \mathrm{~h}$ incubation had no significant relationship with $\mathrm{P}$ additions. At Site L_01E, TN remained at a similar level in all $\mathrm{PO}_{4}{ }^{3-}$ concentrations, but chl $a$ and NF increased slightly in treatments with $\mathrm{P}$ added in comparison to the treatment with no P (Fig. 6). However, the slope values were very low. In addition, the $\mathrm{p}$-values of $\mathrm{R}^{2}$ for linear regression at Site L_01E $\left(\mathrm{NF}, \mathrm{R}^{2}=0.102\right.$; chl $a_{\text {, }}$ $\left.\mathrm{R}^{2}=0.072\right)$ were not significant $(\mathrm{p}=0.07$ and 0.13 for $\mathrm{NF}$ and chl $a$, respectively). However, the p-values were close to 0.05 when unexplained outliers were included; therefore, we conclude that $\mathrm{P}$ may have had a weak control over NF and chl a also at this site. Even if this was so, P would have explained only $10 \%$ or less of variability in NF and chl a.

\section{DISCUSSION}

\section{Nutrient limitation of the phytoplankton community}

Dissolved inorganic and total $\mathrm{N}$ and $\mathrm{P}$ concentrations were typical for the late summer season in the Baltic Sea (Hänninen et al. 2000, Larsson et al. 2001). The TN:TP ratio (56:1 to 102:1) was consistently higher than the Redfield ratio (16:1). Based on this stoichiometric consideration alone, one would not predict high potential for growth of $\mathrm{N}_{2}$-fixing cyanobacteria in the system (Smith 1983). The lower availability of $\mathrm{N}$ than $\mathrm{P}$ in marine organic compounds may help explain this discrepancy (Granéli et al. 1990, Wu et al. 2000).

The DIN:DIP ratio in the surface layer was a much better indicator of nutrient limitation than TN:TP. As suggested by the DIN:DIP ratio, at the gulf water sites where it was higher than 16:1, P limitation of chl a and/or primary productivity prevailed. In contrast, at 2 open sea sites where the ratio was lower than 16:1, $\mathrm{N}$ limitation of chl a occurred (S_00A and S_00B). However, the relationship between the DIN:DIP ratio and nutrient limitation is not straightforward, as demonstrated by the dominance of diazotrophic cyanobacteria and presence of $\mathrm{N}_{2}$ fixation at all sites. Hori- 

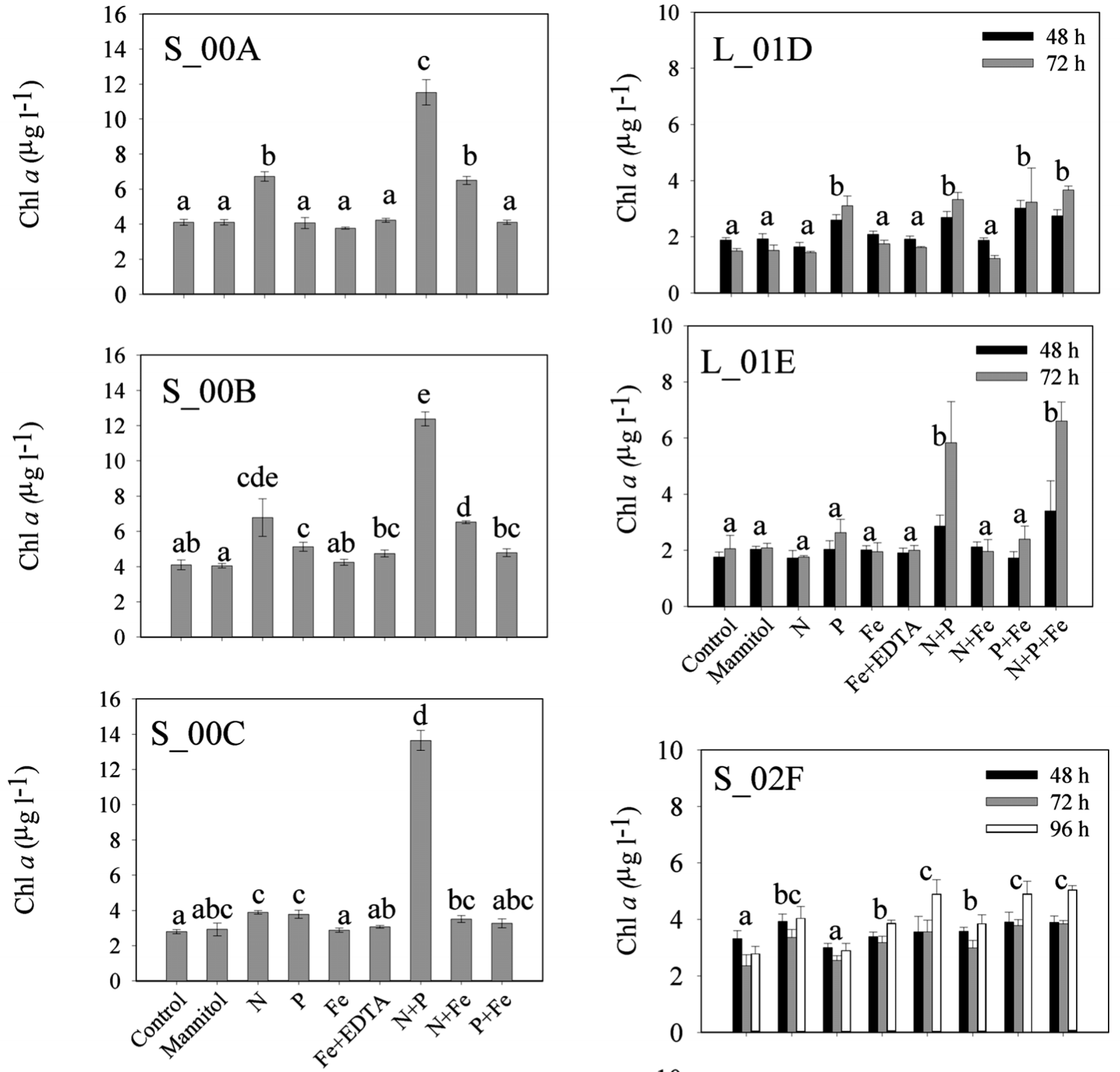

Nutrient addition

Fig. 3. Chl a $\left(\mu \mathrm{g} \mathrm{l}^{-1}\right)$ values in nutrient enrichment experiments. Average values $( \pm \mathrm{SD})$ of 4 Cubitainers per treatment are shown. In experiments on Sites S_00A, S_00B, and S_00C, the measurements were made after a $72 \mathrm{~h}$ incubation. Oneway ANOVA was carried out for S_00A, S_00B, and S_00C, while repeated measures ANOVA was carried out for the sites with multiple sampling time points. All time points shown were included in the Repeated Measures ANOVA. Bonferroni or Dunnet's T3 post hoc pairwise comparisons were used. Same letters above bars indicate non-significant differences of treatments from each other based on post hoc tests. Letters also indicate response levels for the treatments $(\mathrm{a}<\mathrm{b}<\mathrm{c}<\mathrm{d}<\mathrm{e})$. Note varying scales. See Fig. 1 legend for site definitions

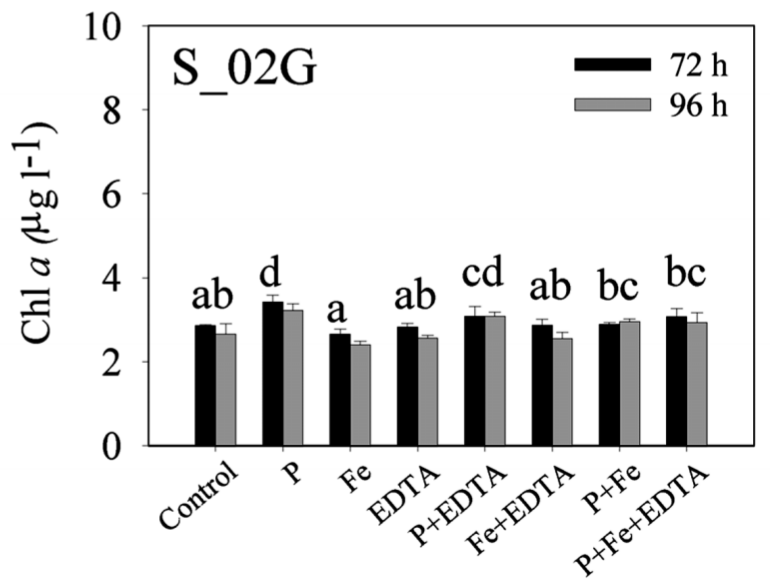

Nutrient addition 
zontal transport and intracellular nutrient storage can contribute to these observations.

In estuaries in the summer situation, it is common to see the highest phytoplankton response level in the $\mathrm{N}+\mathrm{P}$ treatment due to depletion of both of these nutrients (e.g. Fisher et al. 1999). At most sites we observed the strongest response in phytoplankton biomass when both $\mathrm{N}$ and $\mathrm{P}$ were added. At several sites, there was a very low response or no response at all if either nutrient was added alone. At first glance, co-limitation suggests different phytoplankton species responded to nutrient additions simultaneously, as contemporaneous limitation of a single species by multiple nutrients is unlikely (Hecky \& Kilham 1988). However, when examining the data more closely, at Site S_00C there is a small, signif- icant increase in chl a due to additions of either $\mathrm{N}$ or $\mathrm{P}$. At Site L_01E, P-alone stimulated chl a slightly, but the increase was not significantly different from the control. There was also a small initial increase, but an apparent fast saturation of chl a under increasing P concentrations at this site, suggesting 'secondary' limitations. Cell counts show that Monoraphidium sp., Nitzschia spp., small flagellates, and some Chlorophyceae species benefited from simultaneous additions of $\mathrm{N}$ and $\mathrm{P}$ more than when either one of these nutrients was added alone. These observations could be explained by a rapid shift in nutrient limitation for a single species, due to effective utilization of ambient nutrients. It is possible that after the primary (initially) limiting nutrient (e.g. P at Site L_01E) had been added, and

Table 4. Statistically significant differences of nutrient treatments from control. One-way ANOVA or repeated measures ANOVA was used. Results from comparisons of nutrient treatments with control (Dunnet), are shown. M: mannitol; E: EDTA. Grey areas indicate the treatment was not included in the experiment. Sign indicates higher (+) or lower (-) than control with $p \leq 0.05$. At Site L_01D, P+Fe and N+P+Fe were added with EDTA, while at other sites, EDTA was not included in these treatments. To calculate the assimilation (Assim.) numbers at Sites L_01D and L_01E, sum of primary productivity (Prim. prod.) in 0.2 to 2 and $>2 \mu \mathrm{m}$ size fractions were divided by the chl a concentration. $\mathrm{N}_{2}$ fixation values were reported as acetylene reduced per volume (NF) and per unit of chl a (NR). Site codes: S and L denote open Baltic Sea and gulf waters, respectively; numbers refer to years sampled; letters A to G correspond to Sites A to G, e.g. S_00B corresponds to the open sea Site B sampled in 2000

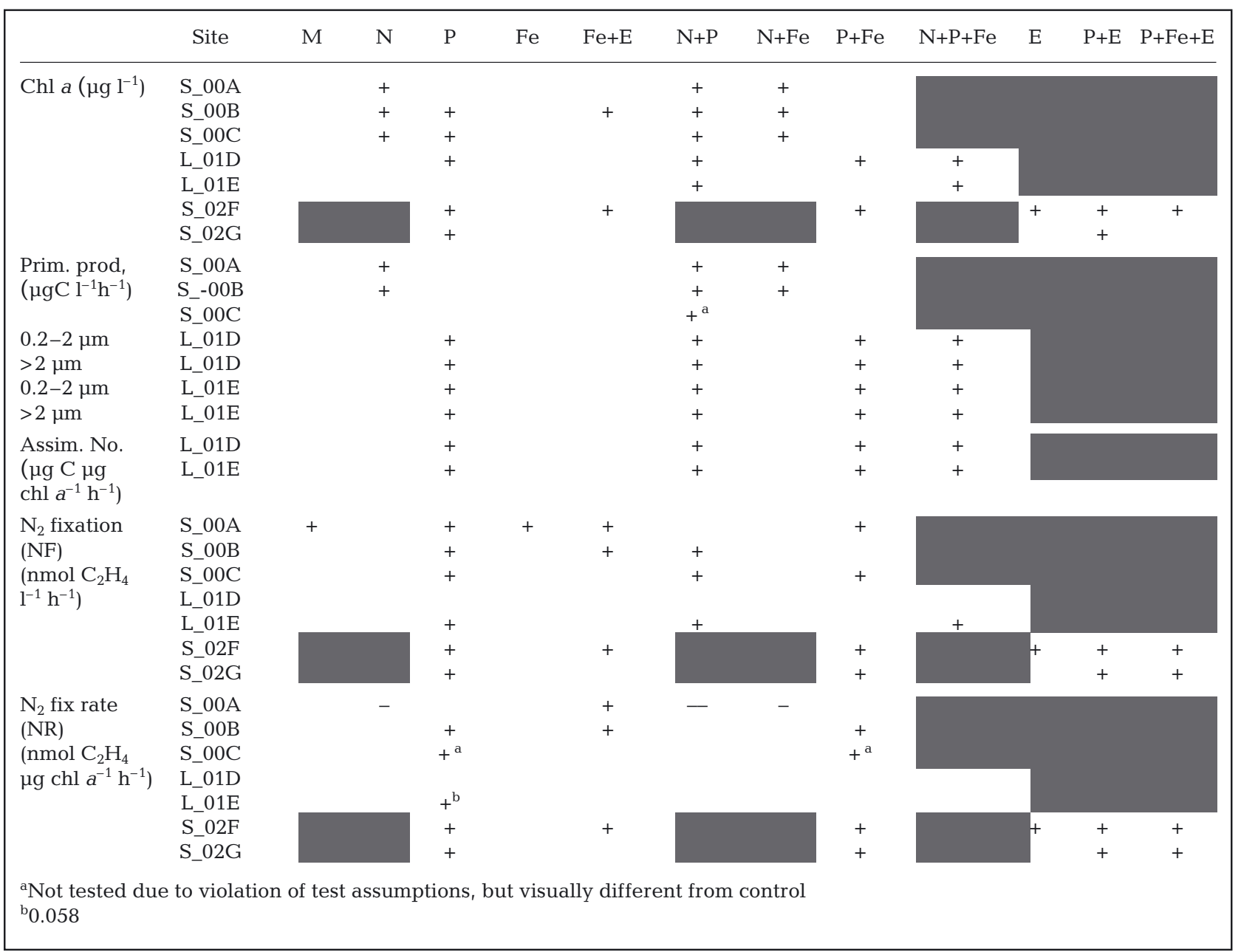


due to its low availability and fast consumption, the 'secondary limiting' nutrient (e.g. N) became limiting very quickly. Therefore, a 'co-limitation' of $\mathrm{N}$ and $\mathrm{P}$ for a single species was observed in several cases, because nutrient limitation for a single species may have changed faster than the experimental design was capable of detecting it. Some variability from this pattern was observed. For example, at Site S_00B, P was not a 'secondary limiting' nutrient for Monoraphidium sp., while this was the case for small flagellates.

It is noteworthy that some repetitive patterns in the phytoplankton species-specific responses to nutrients were observed. Significant responses to nutrient treatments consistently occurred in small cells, such as small flagellates, Monoraphidium sp., and Nitzschia spp., all of which are apparently able to quickly shift into a fast-growth mode in response to amendment of the limiting nutrient. Similar rapid increases of small cells in response to $\mathrm{N}+\mathrm{P}$ additions in Baltic Sea cyanobacterial blooms have been reported previously (Wallström et al. 1992, Kononen et al. 1993). The fact that significant differences between nutrient treat- ments were rarely seen for the cell numbers of filamentous cyanobacteria may stem from both their slower growth rates and their inability to compete effectively for the added nutrients.

There were several small pennate Nitzschia spp. (including $N$. acicularis, $N$. longissima, and another Nitzschia sp.) present in the samples. Epiphytic communities of algae, protozoa, etc., are frequently seen on Nodularia spp. aggregates. In particular, small pennate Nitzschia sp. cells are occasionally found as 'pins' attached to the filaments of the large cyanobacterium (Fig. 7). Because very little is known about the interaction of Nodularia spp. and the epiphytic Nitzschia sp., observations from our experiments are worth discussing. Because these diatoms are not $\mathrm{N}_{2}$ fixers (and presumably don't have $\mathrm{N}_{2}$-fixing symbionts), a symbiotic or consortial relationship between the diatom and Nodularia spp. could be taking place during bloom conditions. These small diatoms might be able to utilize exudates from Nodularia spp. However, the results from this study show that Nitzschia sp. colonization increases rapidly on Nodularia spp. surfaces when $\mathrm{N}$ and $\mathrm{P}$ are

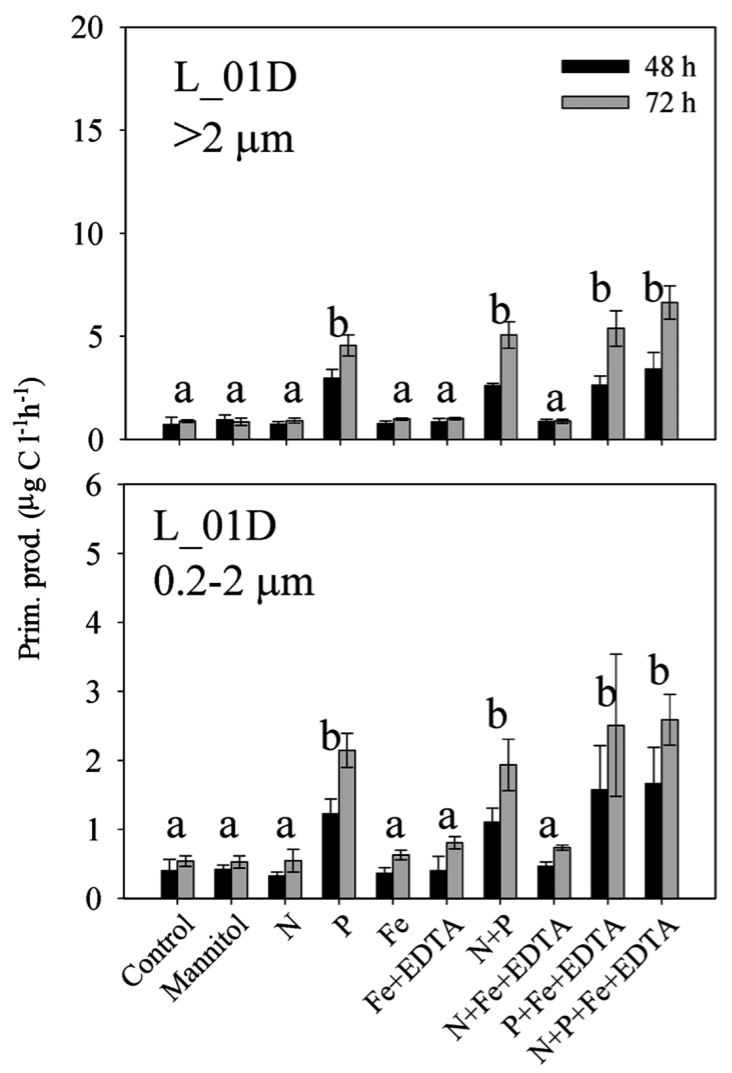

Nutrient addition

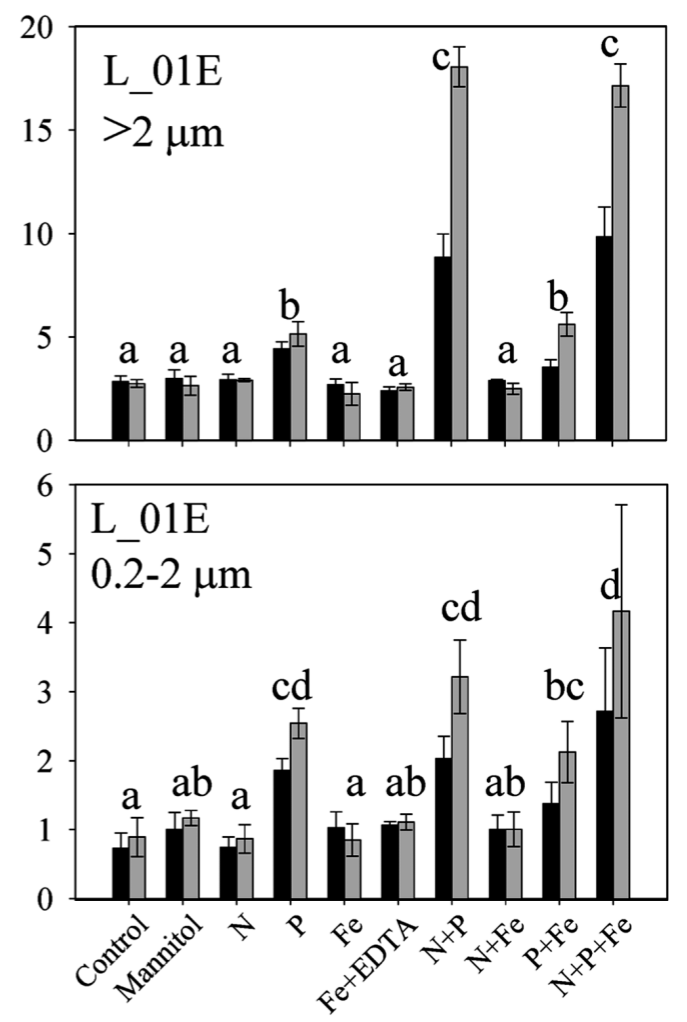

Nutrient addition

Fig. 4. Primary productivity $\left(\mathrm{mg} \mathrm{C}^{-1} \mathrm{~h}^{-1}\right)$ in nutrient-enrichment bioassays from Sites L_01D and L_01E in size fractions 0.2 to 2 and $>2 \mu \mathrm{m}$. Same letters above bars indicate non-significant differences of treatments from each other (repeated measures ANOVA, Bonferroni post hoc test). Letters also indicate response levels for the treatments $(\mathrm{a}<\mathrm{b}<\mathrm{c}<\mathrm{d}<\mathrm{e})$. All time points shown were included in the repeated measures ANOVA. Note varying scales. See Fig. 1 legend for site definitions 

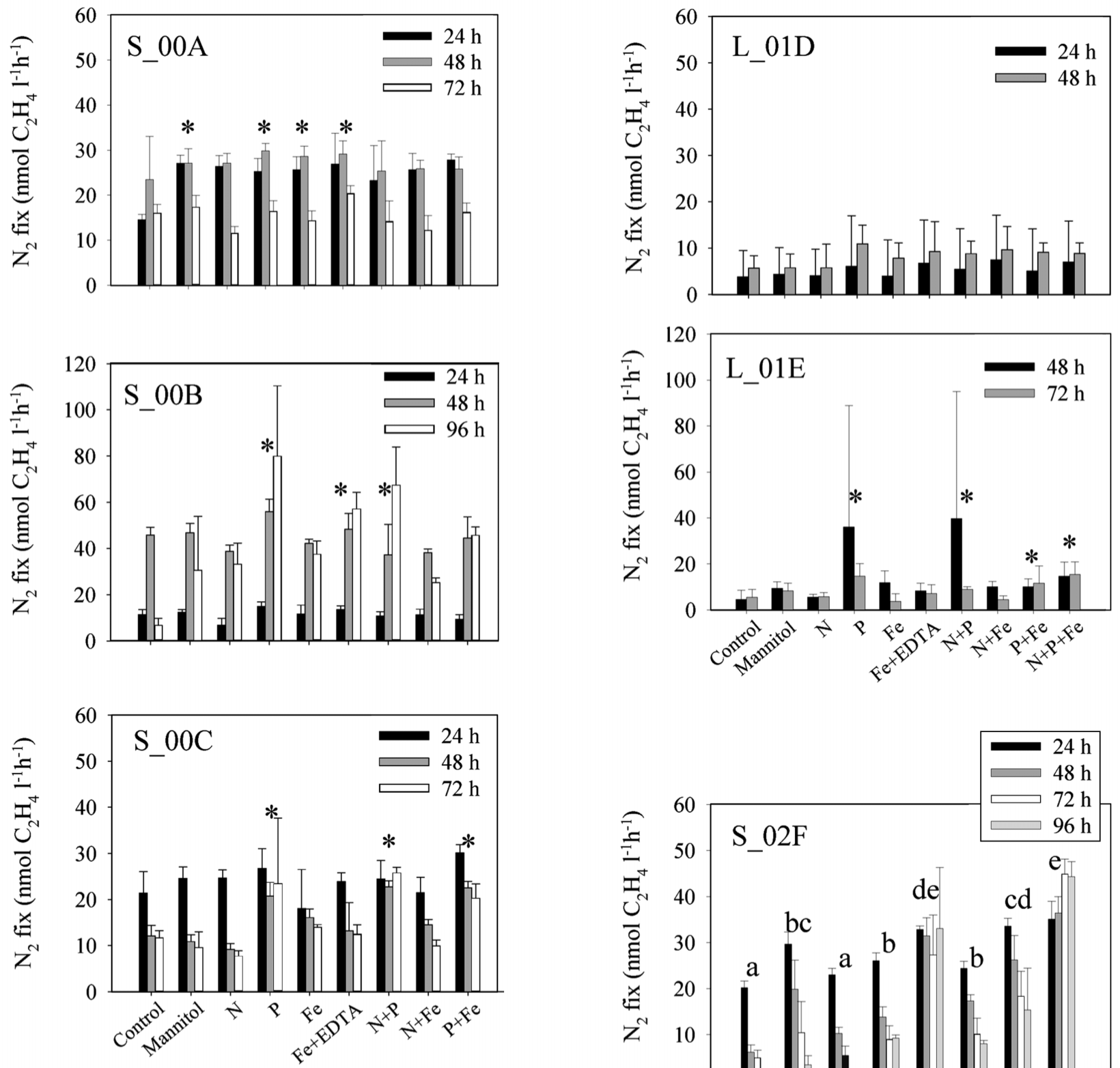

Nutrient addition
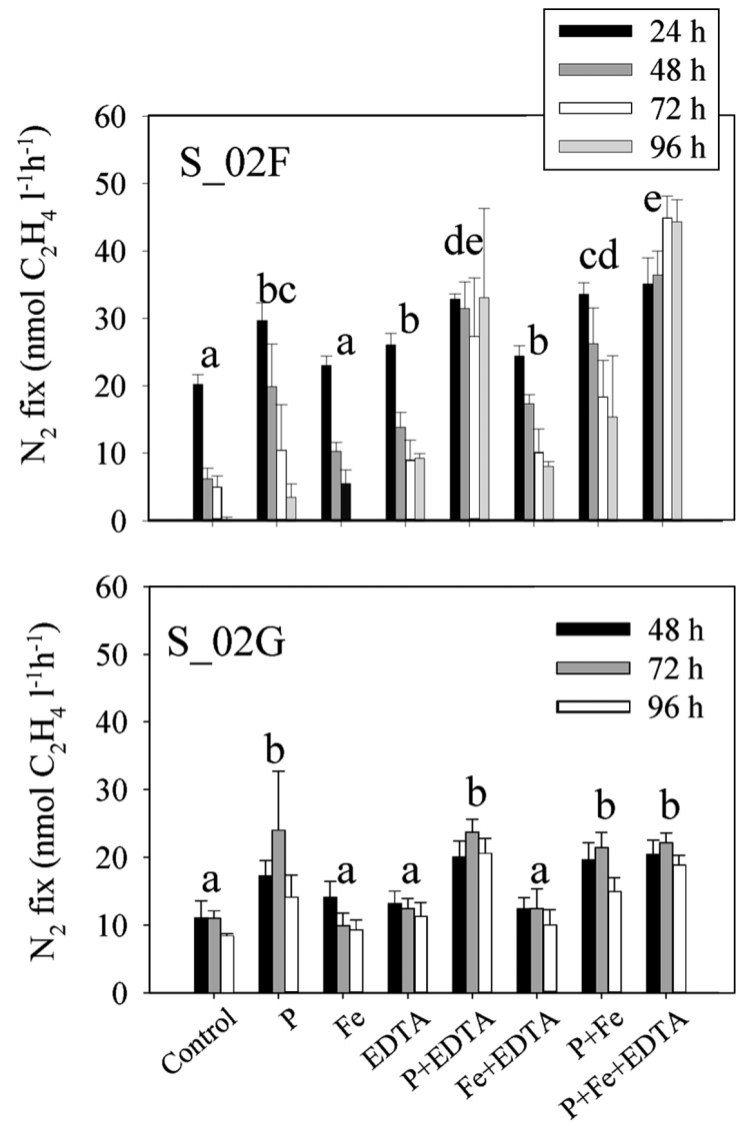

Nutrient addition

Fig. 5. $\mathrm{N}_{2}$ fixation (nmol $\mathrm{C}_{2} \mathrm{H}_{4} \mathrm{~h}^{-1} \mathrm{l}^{-1}$ ) in nutrient enrichment experiments. Average $( \pm \mathrm{SD})$ of 4 cubitainers per treatment are shown. Asterisks indicate significant differences from control (repeated measures ANOVA, Dunnet's post hoc comparison). Same letters above bars indicate non-significant differences of treatments from each other (repeated measures ANOVA, Bonferroni post hoc pairwise comparisons). Letters also indicate response levels for the treatments $(\mathrm{a}<\mathrm{b}<\mathrm{c}<\mathrm{d}<$ e). All time points shown were included in the repeated measures ANOVA. No significant differences from control were found at Site L_01D. Note varying scales. See Fig. 1 legend for site definitions 

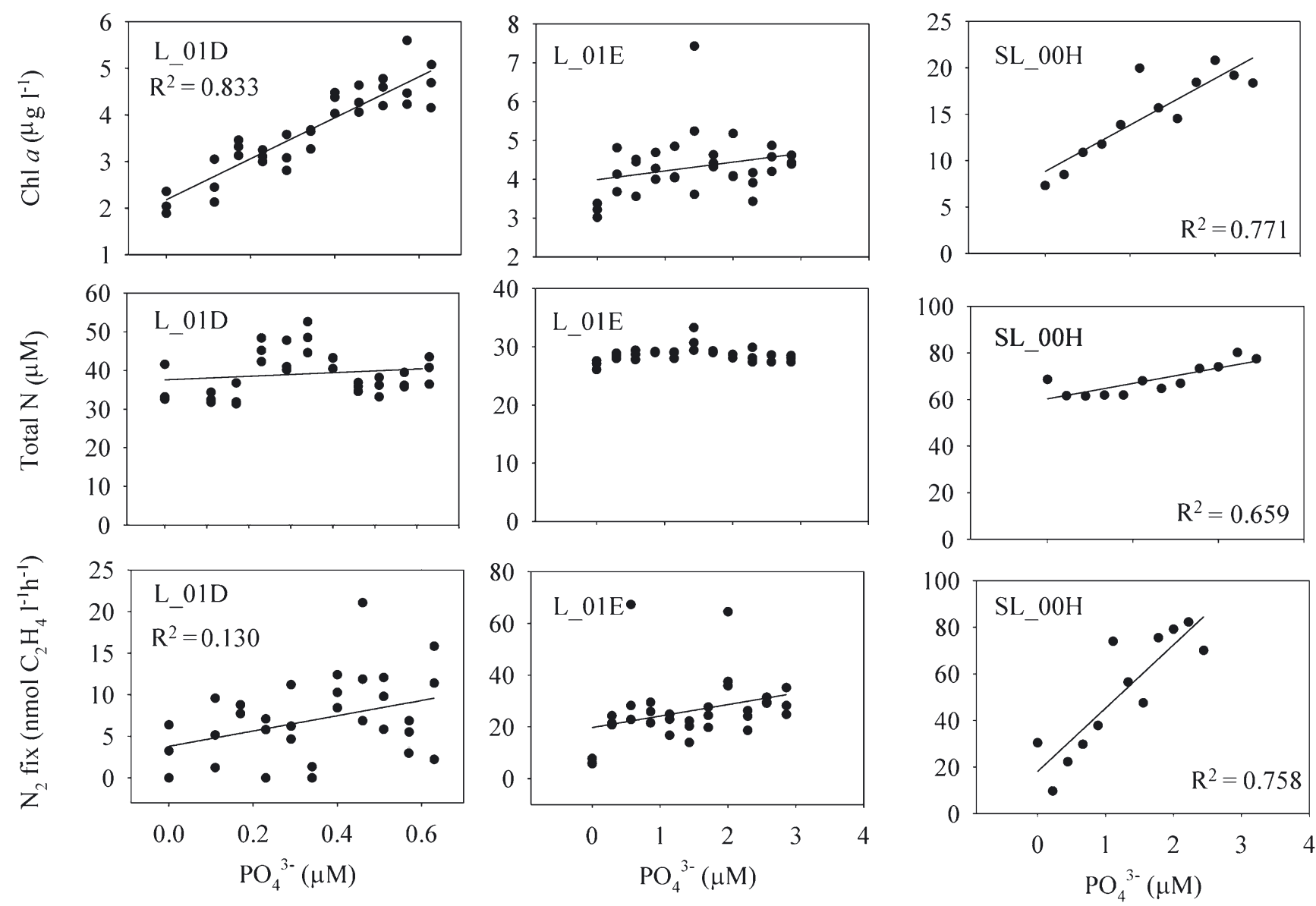

Fig. 6. Effect of $\mathrm{PO}_{4}{ }^{3-}$ concentration on chl a $\left(\mu \mathrm{g} \mathrm{l}{ }^{-1}\right), \mathrm{N}_{2}$ fixation (nmol $\mathrm{C}_{2} \mathrm{H}_{4} \mathrm{l}^{-1} \mathrm{~h}^{-1}$ ), and total $\mathrm{N}$ (TN; $\left.\mu \mathrm{M}\right)$. $\mathrm{PO}_{4}{ }^{3-}$ concentrations shown are the initial concentrations after addition minus ambient concentrations. $\mathrm{R}^{2}$ values are shown for cases where $\mathrm{p}<0.05$ for the linear regression. Note varying scales. See Fig. 1 legend for site definitions

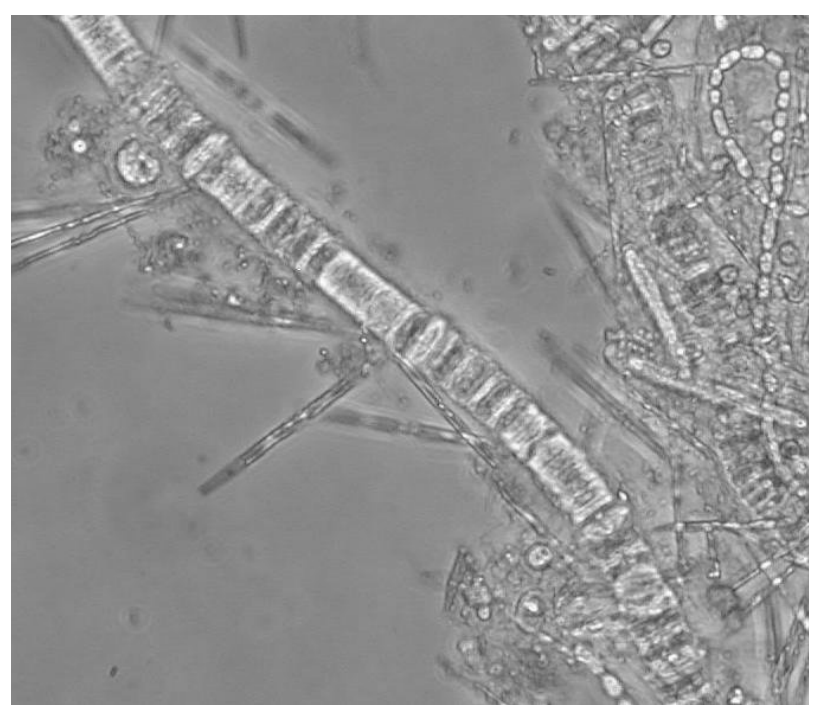

Fig. 7. Nodularia spumigena filaments with attached Nitzschia sp. cells. The image is from the N+P treatment at Site C added (Site S_00C). The results argue against the symbiosis hypothesis above, and suggest that the diatoms are efficient at utilizing external nutrient pulses in their habitat. This may be ecologically more important than reliance on a constant supply of recycled nutrients from Nodularia spp. and associated bacteria. The buoyant, gas-vacuolate, Nodularia spp. aggregates provide a useful surface for maintenance in the euphotic surface layer for the negatively buoyant diatoms, and thus may simply serve as an attachment substrate rather than a nutrient source for the diatoms. Fast growth rates and an ability to attach may enable these small diatoms to flourish opportunistically during external nutrient pulses within the cyanobacterial blooms.

\section{Nutrient limitation of nitrogen fixation}

NF, expressed per volume of water, includes the effect of both growth of $\mathrm{N}_{2}$ fixers and their activity per 
biomass unit. This measure is a useful indicator of the overall response to nutrients in $\mathrm{N}_{2}$ fixers, even though the effects of growth and activity cannot be separated by it. NR can also be used, but because this number includes the error from 2 measurements $\left(\mathrm{N}_{2}\right.$ fixation and chl a) made from the aggregated cyanobacterial community, the values tend to be more variable. Examining both NF and NR produces the most accurate assessment. Addition of $\mathrm{P}$ produced a significant stimulation of $\mathrm{N}_{2}$ fixation (both $\mathrm{NF}$ and NR) at most sites. An exception was Site L_01D, where $\mathrm{N}_{2}$ fixation was low. However, a significant, although weak, linear regression between $\mathrm{N}_{2}$ fixation and $\mathrm{P}$ supply was observed, suggesting that $\mathrm{P}$ was limiting $\mathrm{N}_{2}$ fixation at this site as well. It is noteworthy that even though Nodularia spp. biomass was high at Site L_01D, $\mathrm{N}_{2}$ fixation rates in this population were very low. Since the ambient DIN levels were at the same level as at other sites, it is likely that something (most likely P) was limiting $\mathrm{N}_{2}$ fixation, rather than the fact that Nodularia spp. were relying on alternative DIN sources, or that DIN was inhibiting $\mathrm{N}_{2}$ fixation. If the cyanobacterial population was severely P-stressed, the experimental time-period may not have been long enough to see the stimulation in $\mathrm{N}_{2}$ fixation in response to $\mathrm{P}$ addition at this site. Salinity at Sites L_01D and L_01E was within the suitable range for Nodularia spp. growth (see Moisander \& Paerl 2000).

The level of stimulation by $\mathrm{P}$ alone on $\mathrm{N}_{2}$ fixation was equal to the level of stimulation when $\mathrm{P}$ was added in combination with Fe or N. This supports the overall P-limitation of $\mathrm{N}_{2}$ fixation. The increase in biomass $(\mathrm{chl} a)$ under treatments in which $\mathrm{P}$ and Fe were added together was never at a significantly higher level than in treatments where $\mathrm{P}$ was added alone, and never higher than in treatments in which both $\mathrm{P}$ and $\mathrm{N}$ were added. These results argue against any significant effect of $\mathrm{Fe}$ on $\mathrm{N}_{2}$ fixation. Additionally, at both Sites S_00A and S_00B, where $\mathrm{N}_{2}$ fixation was higher under the Fe treatment than control conditions, Fe was added in combination with EDTA. This may be important, since at Site S_02F, EDTA added alone induced an increase in $\mathrm{N}_{2}$ fixation. Microscopic counts of Anabaena spp. and Aphanizomenon sp. support the $\mathrm{N}_{2}$ fixation results, suggesting that in the prevailing conditions, addition of EDTA was beneficial for growth of $\mathrm{N}_{2}$-fixing cyanobacteria.

EDTA was added in the experiments in order to increase the bioavailability of $\mathrm{Fe}$; however, it may have played several roles in the experiments. First, it may have improved the bioavailability of naturally occuring or experimentally added $\mathrm{Fe}$, or other naturally occurring trace elements (Løvstad \& Krogstad 2001). As a strong chelator, EDTA may have also alleviated toxic effects from metals such as $\mathrm{Cu}$ (Ma et al. 2003). It may have also served as a DOC source for bacteria, which could have made nutrients available for the $\mathrm{N}_{2}$-fixing cyanobacteria by degrading EDTA (Kari \& Giger 1996, Witschel et al. 1999, Satroutdinov et al. 2003). However, the ability to degrade EDTA is not widespread among bacteria (Satroutdinov et al. 2003). Finally, EDTA may have been utilized directly by the cyanobacteria as a C or N source. Baltic Sea cyanobacteria have functional aminopeptidases, thus cyanobacterial utilization of complex organic compounds is possible (Stoecker et al. 2002). Because of its complicated effects on metal speciation and availability in natural waters, and its potential bioavailability, the mechanism causing EDTA stimulation in our experiments is not clear. However, our conclusion remains that, at times, increases in EDTA could be beneficial for cyanobacterial blooms in the Baltic Sea. This is noteworthy, because EDTA is a widely used compound in various industrial processes, and a common water pollutant (eg. Kari \& Giger 1996).

\section{Nutrient dynamics and limitation of $\mathrm{N}_{2}$-fixing blooms in the Baltic Sea}

The prevailing $\mathrm{N}$ limitation in the open Baltic Sea at the time of cyanobacterial blooms was expected. However, P limitation of phytoplankton community-biomass and -productivity at the gulf water sites seems to contradict the commonly held assumption that the Baltic Sea is N-limited at the end of summer. The results from this study underscore differences in nutrient dynamics between sub-basins and coastal versus open sea areas in the Baltic Sea (Wulff et al. 1990). It must be stressed that even though the different regions are connected, they behave differently in terms of their nutrient dynamics. This has importance (e.g. for budget calculations) when estimating contributions of different regions to the inputs of $\mathrm{N}$, through $\mathrm{N}_{2}$ fixation, into the Baltic Sea. The results suggest that the eastern Gulf of Finland and coastal areas along the Gulf have a lower contribution to $\mathrm{N}$ inputs through $\mathrm{N}_{2}$ fixation than the open sea areas, and that although the high biomass of cyanobacteria capable of $\mathrm{N}_{2}$ fixation (including $\mathrm{Nodu}$ laria spp.) is sometimes found at these sites (possibly due to advection), they may not be fixing $\mathrm{N}_{2}$ at high rates. $\mathrm{P}$ limitation along the Gulf of Finland coasts contributes to the poor competitiveness of $\mathrm{N}_{2}$ fixers in these areas.

Our study found support for the hypothesis that the DIN:DIP ratio is controlling $\mathrm{N}_{2}$-fixing cyanobacterial growth and dominance in different regions in the Baltic Sea (Niemi 1979). Open sea sites at the entrance to the Gulf of Finland were N-limited, while the coastal sites in the eastern part of the Gulf of Finland were 
P-limited. However, 'co-limitation' was also present. $\mathrm{N}_{2}$ fixation was stimulated by $\mathrm{P}$ at several sites where both the DIN:DIP ratio and $\mathrm{PO}_{4}{ }^{3-}$ concentration were low (S_00A, S_00B, S_00C, SL_00H), and at sites where $\mathrm{PO}_{4}{ }^{3-}$ was undetectable at the surface (sites L_01D, L_01E), supporting the hypothesis that $\mathrm{P}$ is often limiting $\mathrm{N}_{2}$ fixation in the Baltic Sea. However, at the gulf sites the positive relationship between NF and P concentration was weak, suggesting limitation, control, or inhibition by factors other than $\mathrm{P}$.

The results also show that several opportunistic phytoplankton species taking advantage of nutrient pulses exist along with the cyanobacteria in the system. Some of these species, such as Nitzschia spp., may rely on cyanobacteria (in particular the surfacedependent Nodularia spumigena that does not perform vertical migration) for a physical structure for maintenance in the surface layer. Grazing is not likely to have affected the conclusions, as bottom-up, as opposed to top-down, control of phytoplankton biomass prevails in the Northern Baltic in the summer (Kivi et al. 1993).

An increase in TN in the Baltic Sea surface-layer during summer months has been attributed to $\mathrm{N}_{2}$ fixation by cyanobacteria (Larsson et al. 2001). This study supports the view that $\mathrm{N}_{2}$ fixation can lead to detectable increases in TN in the Baltic Sea surfacelayer during blooms. The results also show that actively $\mathrm{N}_{2}$-fixing cyanobacteria dominate in the Baltic Sea, even at TN:TP ratios far exceeding the Redfield ratio. The magnitude of increase in $\mathrm{TN}$ and $\mathrm{N}_{2}$ fixation are at times strongly controlled by availability of $\mathrm{P}$. At these times, $\mathrm{N}_{2}$ fixation has a strong positive relationship with TN. Even during the short experimental time-period of $3 \mathrm{~d}$, relationship between $\mathrm{N}_{2}$ fixation and TN is clear if $\mathrm{P}$ is the primary limiting nutrient (Site SL_00H, Pearson correlation $=0.835, \mathrm{p}=0.001, \mathrm{n}=11$ ). This relationship is clear for $\mathrm{N}_{2}$-fixing organisms in the absence of 'secondary' limiting resources. However, the control of $\mathrm{N}_{2}$ fixation and $\mathrm{TN}$ by $\mathrm{P}$ is sometimes weak or absent, indicating limitations other than P. If secondary limitations exist, $\mathrm{N}_{2}$ fixation is slow or becomes saturated at a certain $\mathrm{P}$ level, and control of $\mathrm{TN}$ by $\mathrm{N}_{2}$ fixation is not maintained.

The stimulatory effect of EDTA on $\mathrm{N}_{2}$ fixation, and increases in phytoplankton biomass during cyanobacterial blooms in the Baltic Sea, requires further study. Stimulatory effects of dissolved organic matter on cyanobacteria have often been reported elsewhere, but their function is not clear (Fogg et al. 1973), and their role is likely to vary. However, our results suggest that increases in EDTA-like organic compounds in the system could at times improve growth conditions for $\mathrm{N}_{2}$-fixing cyanobacterial blooms in the Baltic Sea.

The cyanobacterial blooms in the Baltic Sea are obvi- ously favored by $\mathrm{N}$ limitation in the late summer; however, N limitation alone does not explain these blooms. Although $\mathrm{N}$ limitation has been demonstrated in diverse marine (including estuarine) planktonic ecosystems, $\mathrm{N}_{2}$ fixation in marine phytoplankton is more rare (Howarth et al. 1988). The question as to why this apparently unfilled niche remains is still unresolved. It is well known that multiple factors, in addition to nutrients, are required for $\mathrm{N}_{2}$-fixing blooms to develop (Fogg et al. 1973, Howarth et al. 1988, Paerl 1990, 1999). The list of potential controlling or limiting factors suggested for $\mathrm{N}_{2}$ fixation in marine environments includes trace elements (Falkowski 1997, Marino et al. 2002), phosphorus (Wu et al. 2000), grazing (Marino et al. 2002), and small-scale shear (Moisander et al. 2002). According to this and previous studies, Nodularia spp. blooms can be linked to high availability of $\mathrm{P}$, warm water temperatures, a stratified water column, and intermediate salinities in the Baltic Sea, the Peel-Harvey estuary in Australia, and the saline Pyramid Lake in the USA (Lukatelich \& McComb 1986, Lebo et al. 1994). In this study, $\mathrm{P}$ was repeatedly limiting $\mathrm{N}_{2}$ fixation and, therefore, presumably the growth of $\mathrm{N}_{2}$ fixers. However, the supply rate of $\mathrm{P}$ in the natural environment in the Baltic Sea has to be sufficient to maintain the blooms. Absence of such a semi-continuous or continuous supply of $\mathrm{P}$ may be a limiting factor for the formation of $\mathrm{N}_{2}$-fixing blooms in certain other marine environments.

Acknowledgements. We thank H. Kuosa (University of Helsinki, Finland) for helpful discussions and insights. The personnel of the Finnish Institute of Marine Research (FIMR) are acknowledged for technical assistance. The nutrient chemistry group at the FIMR provided the nutrient data. We thank the United States Geological Survey for assistance with the study site map. Funding was provided by the Academy of Finland (Finnish Biodiversity Research Programme), U.S. National Science Foundation Projects OCE 9905723 and MCB 0132528, and U.S. EPA STAR Project R82-5243-010.

\section{LITERATURE CITED}

Baltic Marine Environment Protection Commission (1983) Guidelines for the Baltic Monitoring Programme for the second stage. Baltic Sea Environment Proceedings 12, BMEPC, Helsinki

Burris RH (1972) Measurement of biological $\mathrm{N}_{2}$ fixation with ${ }^{15} \mathrm{~N}_{2}$ and acetylene. In: Sorokin YI, Kadota H (eds) Techniques for the assessment of microbial production and decomposition in fresh waters. IBP Handbook 23. Blackwell Scientific International Biological Programme, Oxford, p 3-14

Falkowski PG (1997) Evolution of the nitrogen cycle and its influence on the biological sequestration of $\mathrm{CO}_{2}$ in the ocean. Nature 387:272

Fisher TR, Gustafson AB, Sellner K, Lacouture R and 6 others (1999) Spatial and temporal variation in resource limitation in Chesapeake Bay. Mar Biol 133:763-778 
Flett RJ, Schindler DW, Hamilton RD, Campbell NER (1980) Nitrogen fixation in Canadian Precambrian Shield lakes. Can J Fish Aquat Sci 37:494-505

Fogg GE, Stewart WDP, Fay P, Walsby AE (1973) The bluegreen algae. Academic Press, London

Granéli E, Wallström K, Larsson U, Granéli W, Elmgren R (1990) Nutrient limitation of primary production in the Baltic Sea area. Ambio 19:142-151

Hänninen J, Vuorinen I, Helminen H, Kirkkala T, Lehtilä K (2000) Trends and gradients in nutrient concentrations and loading in the Archipelago Sea, Northern Baltic, in 1970-1997. Estuar Coast Shelf Sci 50:153-171

Healey FP (1982) Phosphate. In: Carr NG, Whitton BA (eds) The biology of cyanobacteria. Blackwell Scientific Publications, Oxford, p 105-124

Hecky RE, Kilham P (1988) Nutrient limitation of phytoplankton in freshwater and marine environments: a review of recent evidence on the effects of enrichment. Limnol Oceanogr 33:796-822

Howarth RW, Marino R, Cole JJ (1988) Nitrogen fixation in freshwater, estuarine, and marine ecosystems. 2. Biogeochemical controls. Limnol Oceanogr 33:688-701

Kahru M, Leppänen JM, Rud O, Savchuk OP (2000) Cyanobacteria blooms in the Gulf of Finland triggered by saltwater inflow into the Baltic Sea. Mar Ecol Prog Ser 207:13-18

Kari FG, Giger W (1996) Speciation and fate of ethylenediaminetetraacetate (EDTA) in municipal wastewater treatment. Water Res 30:122-134

Kivi K, Kaitala S, Kuosa H, Kuparinen J, Leskinen E, Lignell R, Marcussen B, Tamminen T (1993) Nutrient limitation and grazing control of the Baltic plankton community during annual succession. Limnol Oceanogr 38:893-905

Kononen K, Lahdes EO, Grönlund L (1993) Physiological and community responses of summer plankton to nutrient manipulation in the Gulf of Finland (Baltic Sea) with special reference to phosphorus. Sarsia 78:243-253

Kononen K, Kuparinen J, Mäkelä K, Laanemets J, Pavelson J, Nõmmann S (1996) Initiation of cyanobacterial blooms in a frontal region at the entrance to the Gulf of Finland, Baltic Sea. Limnol Oceanogr 41:98-112

Larsson U, Hajdu S, Walve J, Elmgren R (2001) Baltic Sea nitrogen fixation estimated from the summer increase in upper mixed layer total nitrogen. Limnol Oceanogr 46:811-820

Lebo ME, Reuter JE, Goldman CR, Rhodes CL (1994) Interannual variability of nitrogen limitation in a desert lake: influence of regional climate. Can J Fish Aquat Sci 51: 862-872

Levine SN, Schindler DW (1999) Influence of nitrogen to phosphorus supply ratios and physicochemical conditions on cyanobacteria and phytoplankton species in the Experimental Lake Area, Canada. Can J Fish Aquat Sci 56: 451-466

Løvstad Ø, Krogstad T (2001) Effects of EDTA, FeEDTA and soils on the phosphorus bioavailability for diatom and blue-green algal growth in oligotrophic waters studied by transplant biotests. Hydrobiologia 450:71-81

Lukatelich RJ, McComb AJ (1986) Nutrient levels and the development of diatom and blue-green algal blooms in a shallow Australian estuary. J Plankton Res 8:597-618

Ma M, Zhu W, Wang Z, Witkamp GJ (2003) Accumulation, assimilation and growth inhibition of copper on freshwater alga (Scenedesmus supspicatus 86.81 SAG) in the presence of EDTA and fulvic acid. Aquat Toxicol 63:221-228

Margalef R (1978) Life-forms of phytoplankton as survival alternatives in an unstable environment. Oceanol Acta 1: 493-509

Marino R, Chan F, Howarth RW, Pace M, Likens GE (2002)
Ecological and biogeochemical interactions constrain planktonic nitrogen fixation in estuaries. Ecosystems 5:719-725

Moisander PH, Paerl HW (2000) Growth, primary productivity and nitrogen fixation potential of Nodularia spp. (Cyanophyceae) in water from a subtropical estuary in the United States. J Phycol 36:645-658

Moisander PH, Hench JL, Kononen K, Paerl HW (2002) Smallscale shear effects on heterocystous cyanobacteria. Limnol Oceanogr 47:108-119

Niemi Å (1979) Blue-green algal blooms and N:P ratio in the Baltic Sea. Acta Bot Fenn 110:57-61

Omstedt A, Axell LB (2003) Modeling the variations of salinity and temperature in the large Gulfs of the Baltic Sea. Cont Shelf Res 23:265-294

Paerl HW (1990) Physiological ecology and regulation of $\mathrm{N}_{2}$ fixation in natural waters. Adv Microb Ecol 11:305-344

Paerl HW (1999) Physical-chemical constraints on cyanobacterial growth in the oceans. In: Charpy L, Larkum AWD (eds) Marine cyanobacteria, Special Vol. 19. Bull d'Instit Oceanographique Monaco, Monaco, p 319-349

Paerl HW, Willey JD, Go M, Peierls BL, Pinckney JL, Fogel ML (1999) Rainfall stimulation of primary production in western Atlantic Ocean waters: roles of different nitrogen sources and co-limiting nutrients. Mar Ecol Prog Ser 176: 205-214

Parsons TR, Maita Y, Lalli CM (1984) A manual of chemical and biological methods for seawater analysis. 1st edn, Pergamon Press, New York

Pitkänen H, Tamminen T (1995) Nitrogen and phosphorus as production limiting factors in the estuarine waters of the eastern Gulf of Finland. Mar Ecol Prog Ser 129: 283-294

Rydin E, Hyenstrand P, Gunnerhed M, Blomqvist P (2002) Nutrient limitation of cyanobacterial blooms: an enclosure experiment from the coastal zone of the NW Baltic Proper. Mar Ecol Prog Ser 239:31-36

Satroutdinov AD, Dedyukhina EG, Chistyakova TI, Minkevich IG, Eroshin VK, Egli T (2003) Bacterial degradation of EDTA. Microbiology 72:8-11

Smith VH (1983) Low nitrogen to phosphorus ratios favor dominance by blue-green algae in lake phytoplankton. Science 221:669-671

Stahl L, Staal M, Villbrandt M (1999) Nutrient control of cyanobacterial blooms in the Baltic Sea. Aquat Microb Ecol 18:165-173

Stoecker DK, Gustafson DE Jr, Rintala JM (2002) Extracellular proteolytic activity of bloom-forming phytoplankters. Abs 10th Int Conf Harmful Algae. Oct 21-25, 2002, St. Pete Beach, FL. International Society for the Study of Harmful Algae

Tilman D (1982) Resource competition and community structure. Princeton University Press, Princeton

Underwood AJ (1997) Experiments in ecology: their logical design and interpretation using analysis of variance. Cambridge University Press, Cambridge

Wallström K, Johansson S, Larsson U (1992) Effects of nutrient enrichment on planktic blue-green algae in the Baltic Sea. Acta Phytogeogr Suec 78:25-31

Witschel M, Egli T, Zehnder AJB, Wehrli E, Spycher M (1999) Transport of EDTA into cells of the EDTA-degrading bacterial strain DSM 9103. Microbiology 145: 973-983

Wu J, Sunda W, Boyle EA, Karl DM (2000) Phosphate depletion in the Western North Atlantic Ocean. Science 289: 759-762

Wulff F, Stigebrandt A, Rahm L (1990) Nutrient dynamics of the Baltic Sea. Ambio 19:126-133

Submitted: April 2, 2003; Accepted: July 16, 2003

Proofs received from author(s): October 13, 2003 